OPEN ACCESS

Edited by:

Bhim Pratap Singh, Mizoram University, India

Reviewed by:

Gerard Abraham, Indian Agricultural Research Institute,

India

Herdayanto Sulistyo Putro, Institut Teknologi Sepuluh Nopember,

Indonesia

*Correspondence:

Arun K. Mishra

akmishraau@rediffmail.com; akmishraau@hotmail.com

Specialty section:

This article was submitted to Microbial Physiology and Metabolism,

a section of the journa

Frontiers in Microbiology

Received: 18 September 2016 Accepted: 11 November 2016

Published: 29 November 2016

Citation:

Niveshika, Verma E, Mishra AK,

Singh AK and Singh VK (2016) Structural Elucidation and Molecular

Docking of a Novel Antibiotic Compound from Cyanobacterium Nostoc sp. MGL001.

Front. Microbiol. 7:1899 doi: 10.3389/fmicb.2016.01899

\section{Structural Elucidation and Molecular Docking of a Novel Antibiotic Compound from Cyanobacterium Nostoc sp. MGL001}

\author{
Niveshika ${ }^{1}$, Ekta Verma ${ }^{1}$, Arun K. Mishra ${ }^{1 *}$, Angad K. Singh ${ }^{2}$ and Vinay K. Singh ${ }^{3}$ \\ ${ }^{1}$ Laboratory of Microbial Genetics, Department of Botany, Banaras Hindu University, Varanasi, India, ${ }^{2}$ Department of \\ Chemistry, Banaras Hindu University, Varanasi, India, ${ }^{3}$ Centre for Bioinformatics, School of Biotechnology, Banaras Hindu \\ University, Varanasi, India
}

Cyanobacteria are rich source of array of bioactive compounds. The present study reports a novel antibacterial bioactive compound purified from cyanobacterium Nostoc sp. MGL001 using various chromatographic techniques viz. thin layer chromatography (TLC) and high performance liquid chromatography (HPLC). Further characterization was done using electrospray ionization mass spectroscopy (ESIMS) and nuclear magnetic resonance (NMR) and predicted structure of bioactive compound was 9-Ethyliminomethyl-12-(morpholin - 4 - ylmethoxy) -5, 8, 13, 16-tetraaza-hexacene - 2, 3 dicarboxylic acid (EMTAHDCA). Structure of EMTAHDCA clearly indicated that it is a novel compound that was not reported in literature or natural product database. The compound exhibited growth inhibiting effects mainly against the gram negative bacterial strains and produced maximum zone of inhibition at $150 \mu \mathrm{g} / \mathrm{mL}$ concentration. The compound was evaluated through in silico studies for its ability to bind 305 ribosomal fragment (PDB ID: 1YRJ, 1MWL, 1J7T, and 1LC4) and OmpF porin protein (4GCP, 4GCQ, and 4GCS) which are the common targets of various antibiotic drugs. Comparative molecular docking study revealed that EMTAHDCA has strong binding affinity for these selected targets in comparison to a number of most commonly used antibiotics. The ability of EMTAHDCA to bind the active sites on the proteins and $30 S$ ribosomal fragments where the antibiotic drugs generally bind indicated that it is functionally similar to the commercially available drugs.

Keywords: Nostoc sp. MGL001, novel bioactive compound, antibacterial agent, molecular docking, RNA fragments, $\mathrm{OmpF}$ porin protein

\section{INTRODUCTION}

High proportion of drug resistance in bacterial pathogens indicated loss of efficacy of conventional antibiotics as only one third of the diseases could be cured by currently available drugs (Karchmer, 2004; Reynolds et al., 2004; Paterson, 2006). Thus, screening of new biologically active compounds are major thrust area at the present moment (Lahlou, 2013). To date, modern scientific advances in drug discovery could not enable the pace of newer drug development because of very little exploration of natural resources especially microbial metabolites (Cragg and Newman, 2013). Actinomycetes, fungi, unicellular bacteria along with cyanobacteria contributed about 45,38 , 
and $17 \%$, respectively, in producing bioactive metabolites (Berdy, 2005; El-Elimat et al., 2012). Of these organisms, cyanobacteria are photoautotrophic in nature and can grow in presence of small amount of nutrients (Bullerjahn and Post, 2014; Dias et al., 2015). Due to these reasons, utilization of cyanobacteria in scientific studies will be a cost effective approach. Cyanobacteria constitute a rich source of unprecedented novel biologically active metabolites (Singh et al., 2005; Sivonen and Börner, 2008; Prasanna et al., 2010), such as peptides, macrolides, phenolic dilactones, polyketides, and alkaloids each of which originate from different pathway and show a broad spectrum of biological activities (Namikoshi and Rinehardt, 1996; Clardy and Walsh, 2004; Kim and Lee, 2006). Estimate proclaim regarding bioactive compounds in fresh water cyanobacteria shown to exhibit antimicrobial, antifungal, antiviral, antitumor, anticancer, and other pharmacological activities (Gul and Hamam, 2005; Mayer and Hamann, 2005; Singh et al., 2005). Extensive screening programme of cyanobacterial bioactive compounds for antibiotics, pharmaceutical and agricultural application has received considerable attention during the past few decades (Patterson et al., 1994; Khairy and El-Kassas, 2010; Kumar et al., 2010).

Among the cyanobacterial genera screened, Nostoc sp. are distributed throughout tropical and subtropical regions and proved as prodigious procedure of secondary metabolites. Genus Nostoc is highly diversified and reported from various terrestrial and aquatic habitats, and also able to form stable cyanobiont in various symbiosis (Dodds et al., 1995). Nostoc species attracted much attention as number of secondary metabolites were isolated, examined and found to have antiviral and antitumor properties (Dembitsky and Rezanka, 2005). Novel antimitotic compound namely Nostodione A has been reported from Nostoc commune (Kobayashi et al., 1994). Nostoc commune produced novel extracellular diterpenoid having antibacterial activity (Jaki et al., 1999). Potent antitumor agent and antifungal peptolides viz. Cryptophycins which is a cyclic depsipeptides isolated from Nostoc sp. showing excellent activity against broad spectrum of drug sensitive and drug resistant solid tumors, implanted in mice (Trimurtulu et al., 1994). An antiviral compound Cyanovirin$\mathrm{N}$ has been isolated from Nostoc ellipsosporum. Freshwater Nostoc spongiaeforme produced Nostocine A exhibiting adverse effect on growth of microorganisms, algae, cultured plants and animal cell lines as well (Hirata et al., 2003). Boron containing metabolite, Borophycin isolated from marine strains viz. Nostoc linckia and $N$ spongiaeforme var. tenue, and cryptophycin from Nostoc sp. ATCC 53789 and GSV 224 has been found to exhibit potent cytotoxicity against human tumor cell lines (Burja et al., 2001).

Therefore, in the present study cyanobacterium Nostoc sp. MGL001 isolated from fresh water body was used for the screening of antibacterial bioactive compound. Various chromatographic techniques like thin layer chromatography (TLC) and high performance liquid chromatography (HPLC) were performed for purification and purified compound were then subjected to electrospray ionization mass spectrometry (ESIMS) and nuclear magnetic resonance (NMR) spectroscopic analysis for identification and structure elucidation. Additionally, the design approaches mentioned above coupled with the in silico computational toolkit for optimizing interactions between ligand (bioactive compound) and receptor molecules. Here, 30S ribosomal fragment (1YRJ, 1MWL, 1J7T, and 1LC4) (Vicens and Westhof, 2001, 2002, 2003; Han et al., 2005) as well as OmpF porin protein (4GCP, 4GCQ and 4GCS) (Ziervogel and Roux, 2013) was selected as target receptors for molecular docking with ligand.

\section{MATERIALS AND METHODS Isolation and Identification of Cyanobacterium}

The experimental organism cyanobacterium Nostoc sp. MGL001 was collected from local fresh water pond (Kardmeshwar pond) Chitaipur, Varanasi, India $\left(25.2719^{\circ} \mathrm{N}, 82.9676^{\circ} \mathrm{E}\right)$. Pond has an area $5012 \mathrm{~m}^{2}$ with the mean depth approximately $10.3 \mathrm{~m}$. This pond is present in vicinity of the adjacent temples and not connected to any river.

Sample was washed several times with sterile water and unialgal population of cyanobacterial strain was obtained by serially diluting the source inocula and subsequently streaking it on the solidified BG-11 agar medium. The purity of culture was routinely checked by streaking cyanobacterial culture on nutrient agar plates containing $0.5 \%$ of the glucose $(\mathrm{w} / \mathrm{v})$ incubated for $24 \mathrm{~h}$. This process was repeated multiple times until pure micro-colonies were obtained. Further cyanobacterial culture was grown in $500 \mathrm{~mL}$ Erlenmeyer flasks containing BG11 medium (Rippka et al., 1979). The flasks were kept at $25 \pm 2{ }^{\circ} \mathrm{C}$ under white cool fluorescent light at an intensity of $95 \mu \mathrm{mol}$ $\mathrm{m}^{-2} \mathrm{~s}^{-1}$, with a $14 / 10 \mathrm{~h}$ light/dark cycle. Identification of axenic cyanobacterial strain was based on the morphological features (Desikachary, 1959; Komarek, 2013) as well as 16S ribosomal gene amplification (Nübel et al., 1997). The light microscope (Dewinter) attached with a camera was used to study the morphology of filaments and cells. The cell dimensions were measured using software (Dewinter Biowizard 4.1).

To amplify the $16 \mathrm{~S}$ ribosomal gene segment, DNA was extracted from the exponentially grown cyanobacterial culture growing on BG11 media using Himedia Bacterial DNA purification kit (MB505). Concentration of DNA was measured using Bio Spec Nano Spectrophotometer Life Science (Shimadzu Biotech). Eluted DNA was stored in $-20^{\circ} \mathrm{C}$. Amplification of $16 \mathrm{~S}$ rDNA gene was performed using $16 \mathrm{~S}$ rDNA bacteria specific primers $27 \mathrm{~F}$ forward (5'-AGAGTTTGATCCTGGCTCAG-3') and $1492 \mathrm{R}$ reverse (5'-TACGGTTACCTTGTTACGACTT-3') (Weisburg et al., 1991). The PCR amplification (BioRad, DNA Engine, Peltier Thermal Cycler) of $16 \mathrm{~S}$ rDNA was performed using $25 \mu \mathrm{l}$ aliquots containing 20-50 $\mu \mathrm{g}$ DNA template, $0.4 \mu \mathrm{M}$ of each primers, $1.5 \mu \mathrm{M} \mathrm{MgCl}_{2}, 200 \mu \mathrm{M}$ dNTPs, and $1 \mathrm{U} / \mu \mathrm{l} \mathrm{Taq}$ Polymerase. Program followed for PCR amplification was: initial denaturation at $95^{\circ} \mathrm{C}$ for $3 \mathrm{~min}, 30$ cycles of $30 \mathrm{~s}$ denaturation at $94^{\circ} \mathrm{C}, 40 \mathrm{~s}$ annealing at $55^{\circ} \mathrm{C}$, and $50 \mathrm{~s}$ extension at $72^{\circ} \mathrm{C}$ and final extension at $72^{\circ} \mathrm{C}$ for $20 \mathrm{~min}$ (Singh et al., 2015). The amplified product was analyzed on a $1.2 \%$ agarose gel stained with ethidium bromide in $1 \mathrm{X}$ TBE buffer and then visualized 

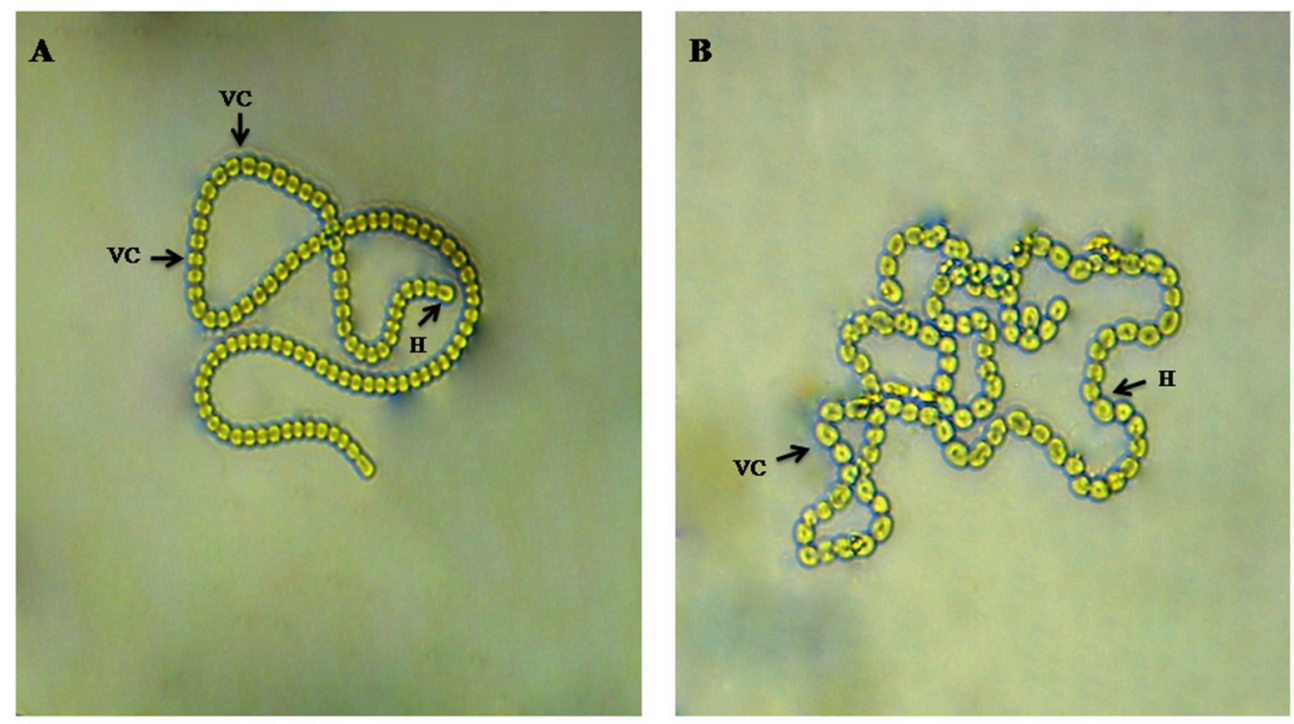

FIGURE 1 | Microphotographs of Nostoc sp. MGL001. (A) and (B) showing filament with vegetative cell (VC) and heterocysts (H).

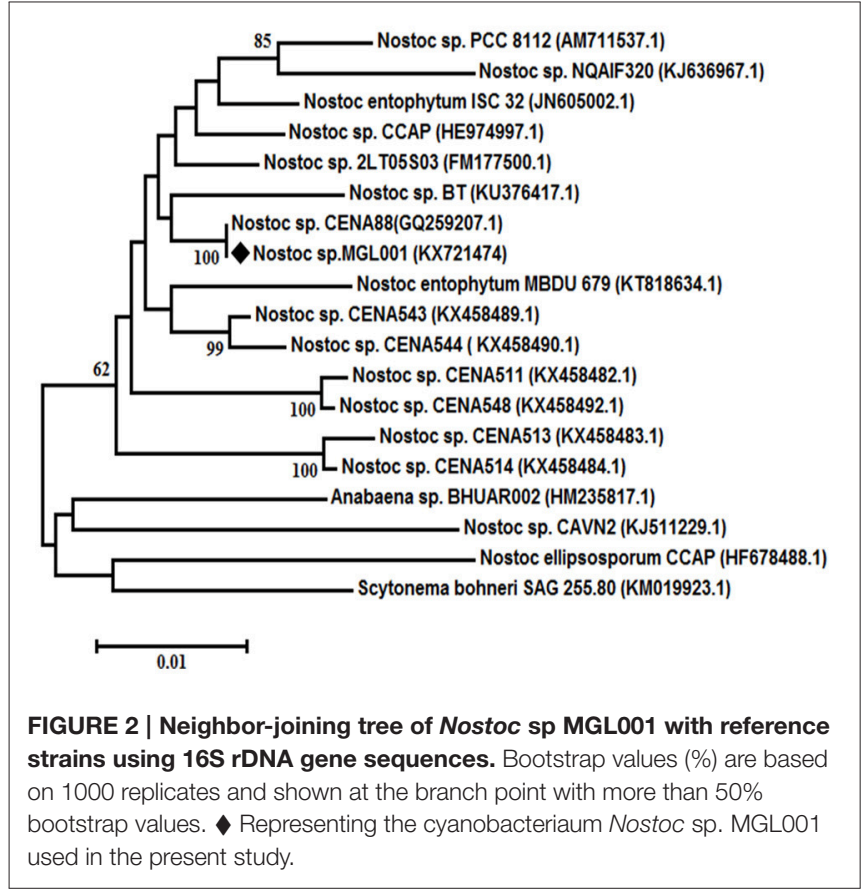

under gel documentation system. The obtained bands were further cut down and eluted using Qiagen quick Gel Extraction kit. The eluted amplified products were finally sent to Sci Genome Cochin, Kerala, India for sequencing.

\section{Nucleotide Sequence Analysis and Construction of Phylogenetic Tree}

The partial 16S rDNA sequence obtained from DNA sequencing was then subjected to NCBI sequence database
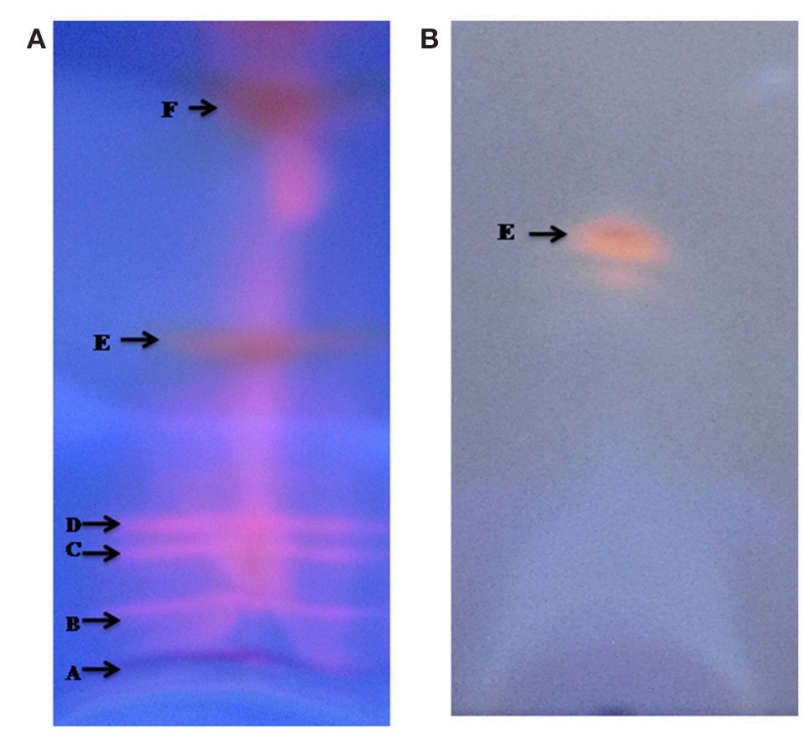

FIGURE 3 | TLC pattern of methanolic crude extract from Nostoc sp. MGL001 (A) using carbon tetrachloride and methanol (9:1) as mobile solvent. (B) TLC pattern of 2nd TLC spot using ethyl acetate and hexane (1:1) as mobile solvent.

viz. nucleotide basic local alignment search tool (Blastn) (http://blast.ncbi.nlm.nih.gov/Blast.cgi) and aligned with the already existing gene sequences of different cyanobacterial species. Furthermore, the partial $16 \mathrm{~S}$ rDNA sequence of the experimental organism was submitted to the NCBI database using the Sequin submission tool version 15.10. Evolutionary history of closely related sequence in a BLAST search was inferred by neighbor joining algorithm method for construction 


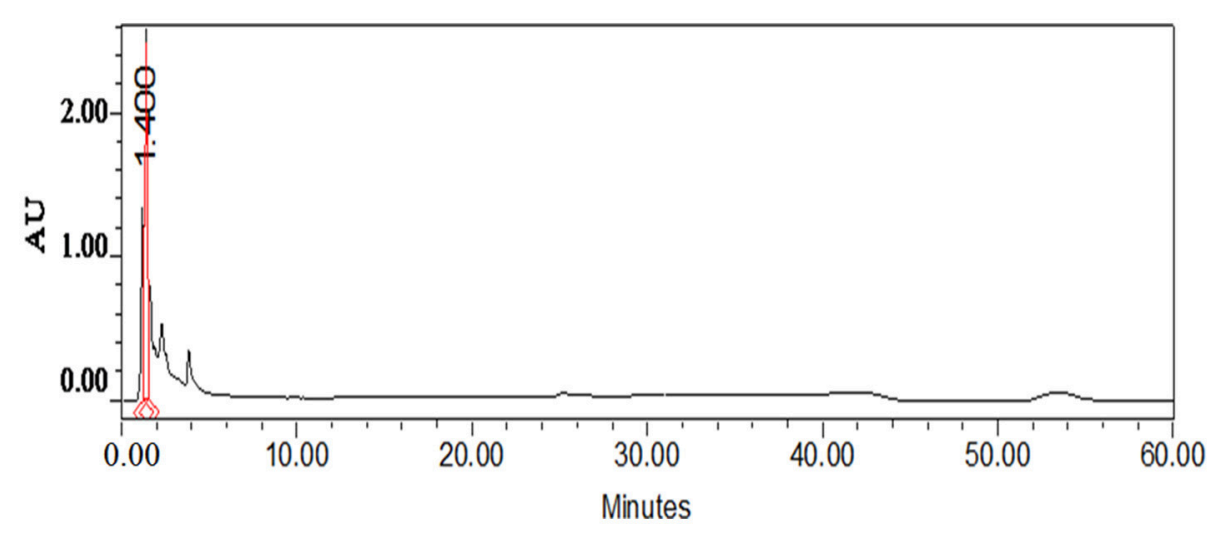

FIGURE 4 | HPLC chromatogram of the spot "E" fraction of the Nostoc sp. MGL001 crude extract obtained from TLC.

TABLE 1 | Antibacterial activity of the EMTAHDCA compound against gram negative bacteria.

\begin{tabular}{|c|c|c|c|c|}
\hline \multirow[t]{2}{*}{ Test organism } & \multicolumn{4}{|c|}{ Inhibition zone $(\mathrm{mm})$ at different concentrations of EMTAHDCA $(\mu \mathrm{g} / \mathrm{mL})$} \\
\hline & 100 & 150 & 200 & 250 \\
\hline E. coli & $4.78 \pm 0.324$ & $11.15 \pm 0.117$ & $11.13 \pm 0.123$ & $11.15 \pm 0.133$ \\
\hline P. vulgaris & $5.22 \pm 0.221$ & $10.17 \pm 0.235$ & $10.16 \pm 0.353$ & $10.16 \pm 0.271$ \\
\hline$P$. aeruginosa & $4.11 \pm 0.356$ & $9.16 \pm 0.211$ & $9.15 \pm 0.233$ & $9.15 \pm 0.279$ \\
\hline
\end{tabular}

of phylogenetic tree (Saitou and Nei, 1987). Evolutionary analysis was performed using MEGA 6 software (Tamura et al., 2013).

\section{Preparation of Crude Extract}

For the preparation of crude extract 40-45 days old cyanobacterial culture was used based on the method of Doan et al. (2000). Cyanobacterial cells (10 g fresh weight) were harvested by centrifugation at $10,000 \mathrm{rpm}$ for $15 \mathrm{~min}$ (Remi, India) and then lyophilized (Christ-Alpha 1-2, Germany). Lyophilized cyanobacterial biomass (5g) was extracted twice or thrice in $300 \mathrm{~mL}$ methanol (100\%) by keeping it on shaker (150 rpm for $48 \mathrm{~h}$ ) and centrifuged at $10,000 \mathrm{rpm}(15 \mathrm{~min})$. Supernatant was evaporated to dryness using rotary vacuum evaporator (Perfit, India) at $40^{\circ} \mathrm{C}$ and redissolved in $5 \mathrm{~mL}$ of $100 \%$ methanol for further use.

\section{Thin Layer Chromatography (TLC)}

Dried crude extract of Nostoc sp. MGL001 was dissolved in methanol and purified by TLC (TLC silica gel 60, Merck, Darmstadt, Germany). In this process, carbon tetrachloride: methanol (9:1) was used as the mobile phase and silica was used as the stationary phase. The UV-illuminated orange bands on the TLC plate were designated as A, B, C, D, E, and $\mathrm{F}$, which were dissolved separately in $100 \%$ methanol $(1 \mathrm{~mL})$. Further each elute was then subjected to TLC purification using ethyl acetate: $n$-hexane (1:1). Only the potent designated bands of the first step were subjected to the second step.

\section{Purification of the Antibacterial Compound Produced by Nostoc sp. MGL001 by High Performance Liquid Chromatography (HPLC) Fractionation}

Potent band elute after second step of TLC was dissolved in HPLC grade methanol. Separation was achieved using HPLC (Waters, USA) equipped photodiode array (PDA) detector and inline degasser. The reverse phase Nova pack $\mathrm{C}_{18}$ Spherisorb S10 ODS column $(4.6 \times 150 \mathrm{~mm}, 5 \mathrm{~mm}$ particle size $)$ was used and temperature maintained at $40^{\circ} \mathrm{C}$. Mobile phase consists of Milli-Q water (A) and acetonitrile (B), containing 0.05\% trifluoroacetic acid. All solvents used in study were HPLC grade and filtered through a $0.22 \mu \mathrm{m}$ membrane filter. For mobile phase, linear gradient programme was: $0 \mathrm{~min} 25 \%$ B, $35 \mathrm{~min} 70 \% \mathrm{~B}, 37 \mathrm{~min} 70 \% \mathrm{~B}, 38 \mathrm{~min} 25 \% \mathrm{~B}, 60 \mathrm{~min}$ $25 \%$ B (Lawton et al., 1994). Flow rate of $1 \mathrm{ml} \mathrm{min}^{-1}$ was maintained for sample run and separation was monitored at 200-300 nm (Harada et al., 1999) having $1.2 \mathrm{~nm}$ resolution. Empower2 software was used for instrumentation and data acquisition.

\section{Antibacterial Assay}

Pure fraction of bioactive compound was collected through HPLC and concentrated using rotary vacuum evaporator. Concentrated solid mass of pure bioactive compound were weigh. In order to perform antibacterial assay different concentrations of pure bioactive compound were prepared viz. $100,150,200$, and $250 \mu \mathrm{g} / \mathrm{mL}$ in the volume of $1 \%$ methanol separately. Antibacterial activity was tested by agar disc diffusion 


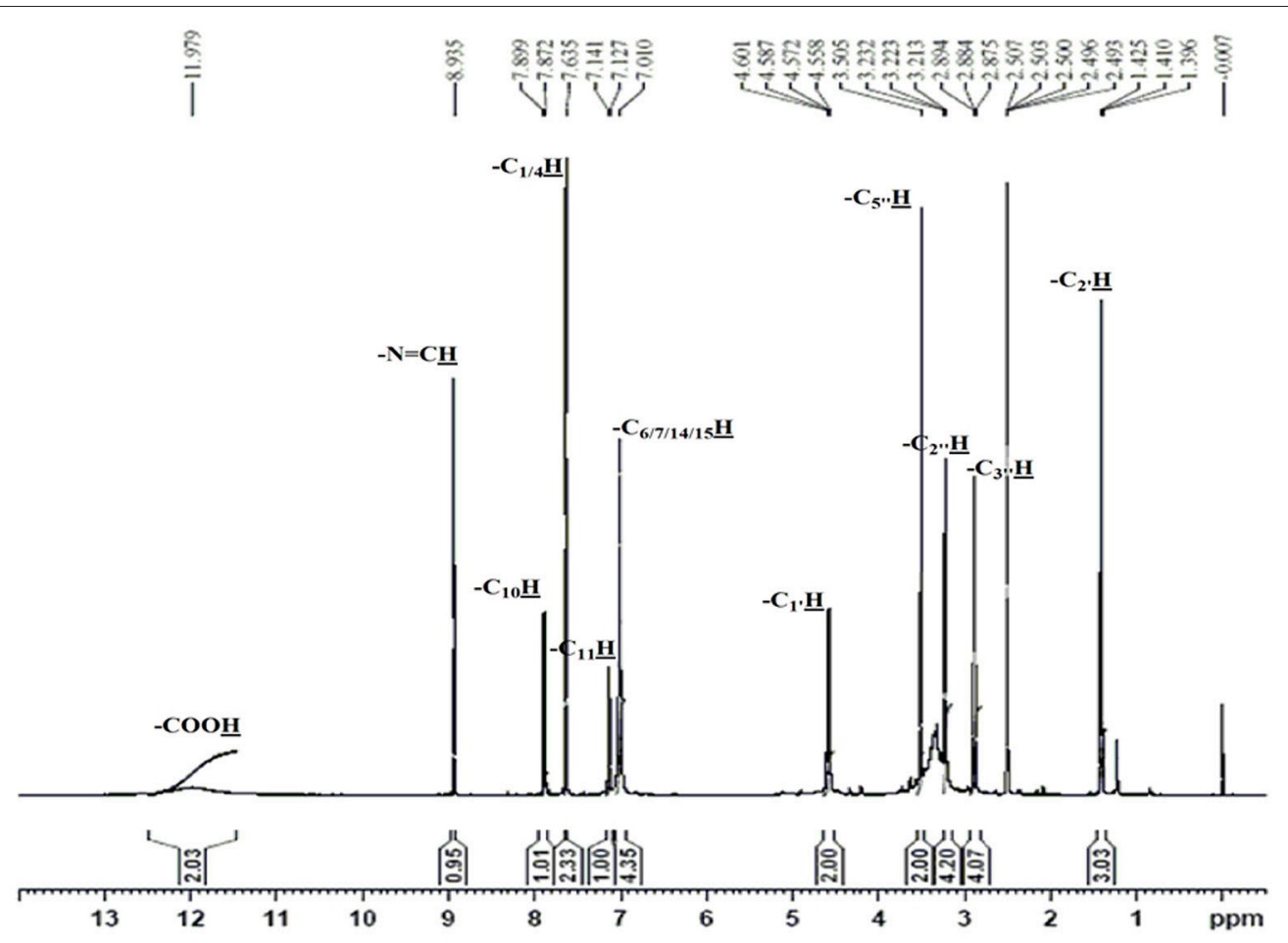

FIGURE 5 | ${ }^{1}$ H NMR spectrum of the bioactive compound (spot "E" eluate) derived from Nostoc sp. MGL001.

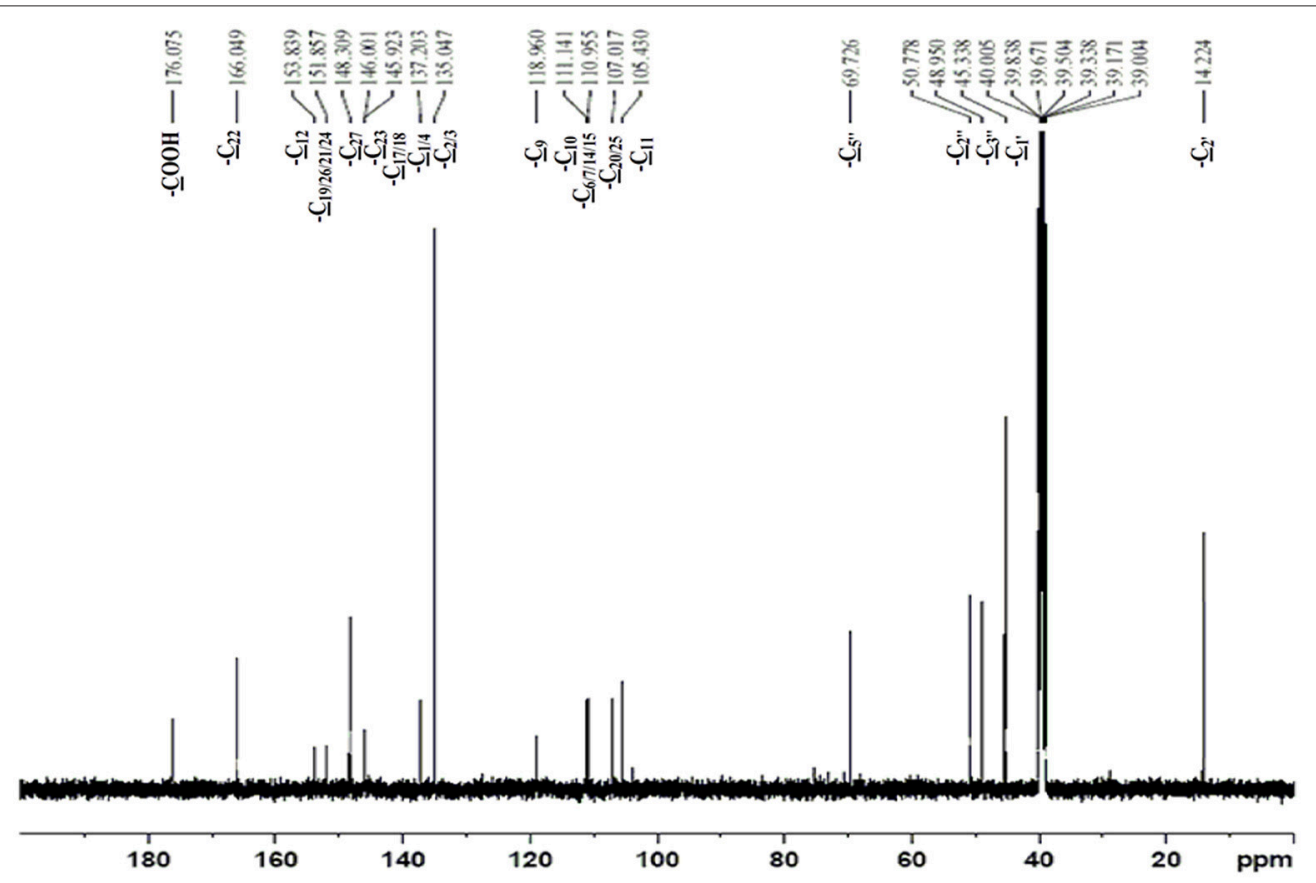

FIGURE $6 \mid{ }^{13} \mathrm{C}$ NMR spectrum of the bioactive compound (spot "E" eluate) derived from Nostoc sp. MGL001.

method using $5 \mathrm{~mm}$ diameter filter paper discs. Agar was inoculated with a standardized quantity of the suspension of the test organisms. Known amount of pure bioactive compound were loaded on filter paper discs. Control discs received only the solvent ( $1 \%$ methanol). Discs were allowed to remain at room temperature until complete solvent evaporation and then placed 
on the seeded agar plates. The diameter of the inhibition zone (from periphery of disc to periphery of zone) was measured in $\mathrm{mm}$ after $24 \mathrm{~h}$ incubation at $37^{\circ} \mathrm{C}$.

\section{ESI-MS and NMR Studies}

Electrospray ionization (ESI) equipped with time of flight mass spectrometer were recorded on Bruker daltonics AmaZon SL. Capillary voltage $3500 \mathrm{~V}$ in positive ion mode was set having $20 \mu \mathrm{L} / \mathrm{min}$ flow rate. The ${ }^{1} \mathrm{H}, \mathrm{H}-\mathrm{H}$ COSY, ${ }^{13} \mathrm{C}\left\{{ }^{1} \mathrm{H}\right\}$, DEPT135, and DEPT-90 NMR spectra were recorded on a Bruker AVANCE III HD-500 MHz multinuclear FTNMR spectrometer at $25^{\circ} \mathrm{C}$.

\section{Optimization of Isolated Bioactive Compound and Docking Study}

For visualization of isolated compound Discovery Studio 3.0 tool was used (Gao and Huang, 2011).

\section{TABLE 2 | NMR Spectral data of EMTAHDCA.}

\begin{tabular}{|c|c|c|c|c|}
\hline S. No. & $\begin{array}{l}{ }^{1} \mathrm{H} /{ }^{13} \mathrm{C}\left\{{ }^{1} \mathrm{H}\right\} \\
\text { (Multiplicity) }\end{array}$ & No. of proton & Peak position $(\delta)$ & $\begin{array}{c}\text { Coupling } \\
\text { constant } \\
{ }^{3} J_{H-H}(\mathrm{~Hz})\end{array}$ \\
\hline 1 & $-\mathrm{COOH}(\mathrm{s})$ & 02 & 11.979 & - \\
\hline 2 & $-\mathrm{N}=\mathrm{C} \underline{\mathrm{H}}(\mathrm{s})$ & 01 & 8.935 & - \\
\hline 3 & $-\mathrm{C}_{10} \underline{\mathrm{H}}(\mathrm{d})$ & 01 & 7.899-7.872 & 13.50 \\
\hline 4 & $-\mathrm{C}_{1 / 4} \underline{\mathrm{H}}(\mathrm{s})$ & 02 & 7.635 & - \\
\hline 5 & $-\mathrm{C}_{11} \underline{\mathrm{H}}(\mathrm{d})$ & 01 & $7.141-7.127$ & 7.0 \\
\hline 6 & $-\mathrm{C}_{6 / 7 / 14 / 15} \underline{\mathrm{H}}(\mathrm{s})$ & 04 & 7.010 & - \\
\hline 7 & $-\mathrm{C}_{1^{\prime}} \underline{\mathrm{H}}(\mathrm{q})$ & 02 & $4.601-4.558$ & $7.5 / 7.5$ \\
\hline 8 & $-\mathrm{C}_{5^{\prime \prime}} \underline{\mathrm{H}}(\mathrm{s})$ & 02 & 3.505 & - \\
\hline 9 & $-\mathrm{C}_{2^{\prime \prime}} \underline{\mathrm{H}}(\mathrm{t})$ & 04 & $3.232-3.213$ & 5.0 \\
\hline 10 & $-\mathrm{C}_{3^{\prime \prime}} \underline{\mathrm{H}}(\mathrm{t})$ & 04 & $2.894-2.875$ & 5.0 \\
\hline 11 & $-\mathrm{C}_{2^{\prime}} \underline{\mathrm{H}}(\mathrm{t})$ & 03 & $1.425-1.396$ & 7.0 \\
\hline 12 & $-\underline{\mathrm{COOH}}$ & - & 176.08 & - \\
\hline 13 & $-\underline{\mathrm{C}}_{22}$ & - & 166.05 & - \\
\hline 14 & $-\underline{C}_{12}$ & - & 153.84 & - \\
\hline 15 & $-\underline{\mathrm{C}}_{19 / 26 / 21 / 24}$ & - & 151.86 & - \\
\hline 16 & $-\underline{\mathrm{C}}_{27}$ & - & 148.31 & - \\
\hline 17 & $-\underline{\mathrm{C}}_{23}$ & - & 146.00 & - \\
\hline 18 & $-\underline{C}_{17 / 18}$ & - & 145.92 & - \\
\hline 19 & $-\underline{C}_{1 / 4}$ & - & 137.20 & - \\
\hline 20 & $-\underline{\mathrm{C}}_{2 / 3}$ & - & 135.05 & - \\
\hline 21 & $-\underline{C}_{9}$ & - & 118.96 & - \\
\hline 22 & $-\underline{\mathrm{C}}_{10}$ & - & 111.14 & - \\
\hline 23 & $-\underline{\mathrm{C}}_{6 / 7 / 14 / 15}$ & - & 110.96 & - \\
\hline 24 & $-\underline{\mathrm{C}}_{20 / 25}$ & - & 107.02 & - \\
\hline 25 & $-\underline{C}_{11}$ & - & 105.43 & - \\
\hline 26 & $-\underline{\mathrm{C}}_{5^{\prime \prime}}$ & - & 69.73 & - \\
\hline 27 & $-\underline{\mathrm{C}}_{2^{\prime \prime}}$ & - & 50.78 & - \\
\hline 28 & $-\underline{\mathrm{C}}_{3^{\prime \prime}}$ & - & 48.95 & - \\
\hline 29 & $-\underline{\mathrm{C}}_{1^{\prime}}$ & - & 45.34 & - \\
\hline 30 & $-\underline{C}_{2^{\prime}}$ & - & 14.22 & - \\
\hline
\end{tabular}

s, singlet; q, quartet; $d$, doublet; $t$, triplet.

\section{Selection of Target Structures}

The small ribosomal subunit (30S) fragment and protein structures were selected for interaction with isolated bioactive compound (ligand). The 3-D crystal structure of the target viz. the RNA fragments (1YRJ, 1MWL, 1J7T, and 1LC4) (Vicens and Westhof, 2001, 2002, 2003; Han et al., 2005) and OmpF porin structures (4GCP, 4GCQ, and 4GCS) (Ziervogel and Roux, 2013) were retrieved from the protein databank (PDB) (www.rcsb.org/pdb) and further used for interaction calculation using YASARA software (Krieger and Vriend, 2014). Active site of the targeted protein was predicted using MetaPocket 2.0 (http://projects.biotec.tu-dresden.de/metapocket/) (Huang, 2009; Zhang et al., 2011).

\section{Receptor Preparation and Docking}

The complexes of RNA fragments and porin protein with heteroatom, water molecules and ligands were taken for receptor preparation. The heteroatom, water molecules and ligands were removed using Discovery Studio 3.1 before docking. The Docking calculation was performed for RNA fragments and porin protein with ligand (bioactive compound). The target protein was set in YASARA to run macro file (dock_run.mcr). The YASARA structure provides Autodock and VINA tools to dock ligands with proteins at the touch of a button (Morris et al., 1998; Trott and Olson, 2010).

\section{RESULTS}

\section{Isolation and Identification}

The morphological study of the cyanobacterium Nostoc sp. MGL001 showed that it contains squarish to cylindrical vegetative cells (Figure 1). Nostoc sp. MGL001 (GenBank, accession no. KX721474) and other close homologs for the cyanobacterium can be found from the alignment view tree (Figure 2).

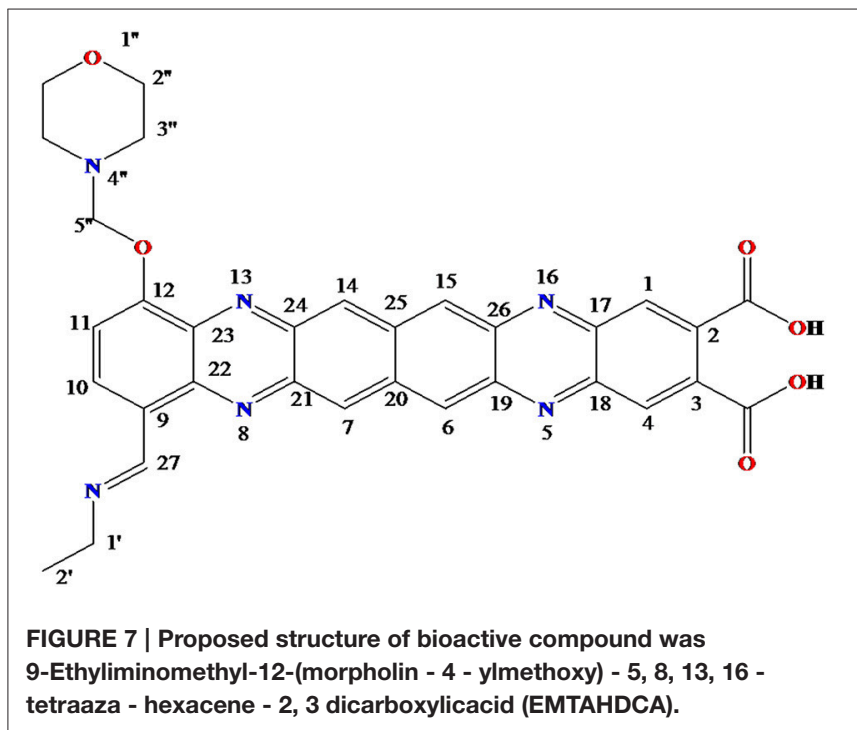



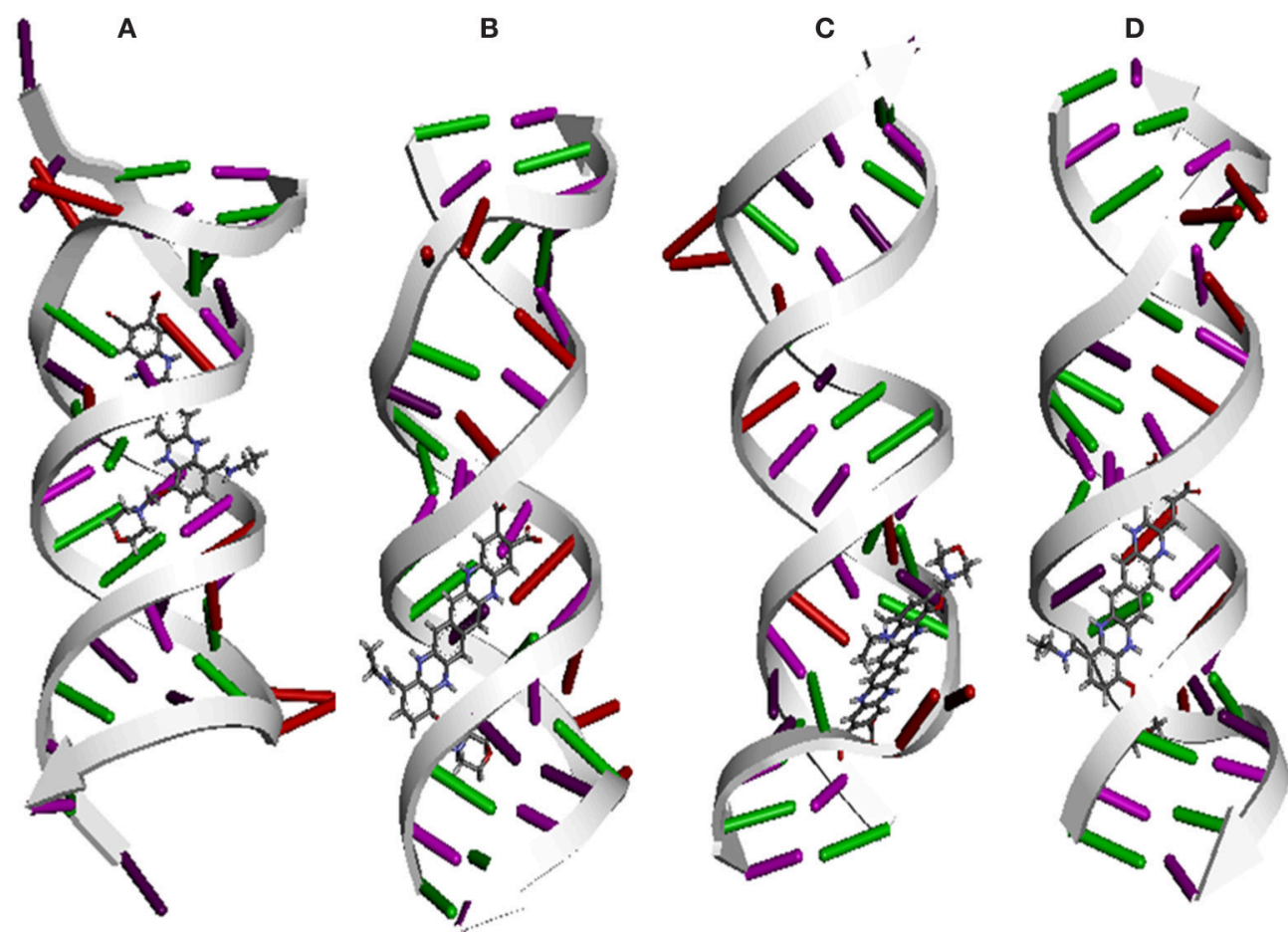

FIGURE 8 | In silico interaction between selected ligand (EMTAHDCA) and target RNA fragment (A) 1YRJ (B) 1MWL, (C) 1J7T, (D) 1LC4.
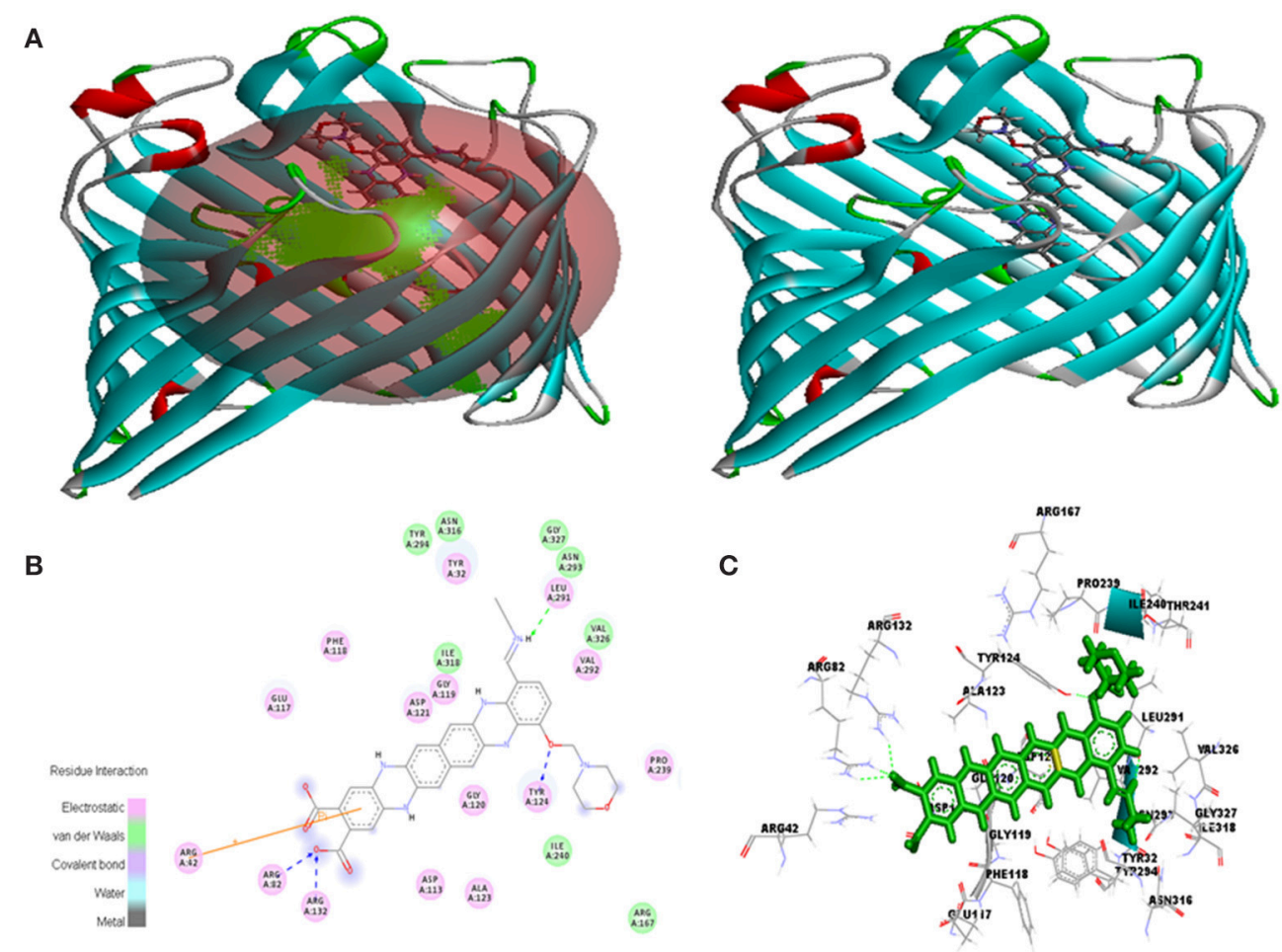

FIGURE 9 | In silico interaction between selected ligand (EMTAHDCA) and target OmpF porin protein (4GCP). (A) Poses of docked complexes, green color in sphere indicates prominent active site where the ligand interacted, (B) 2D level interaction, (C) 3D level interaction. 
A

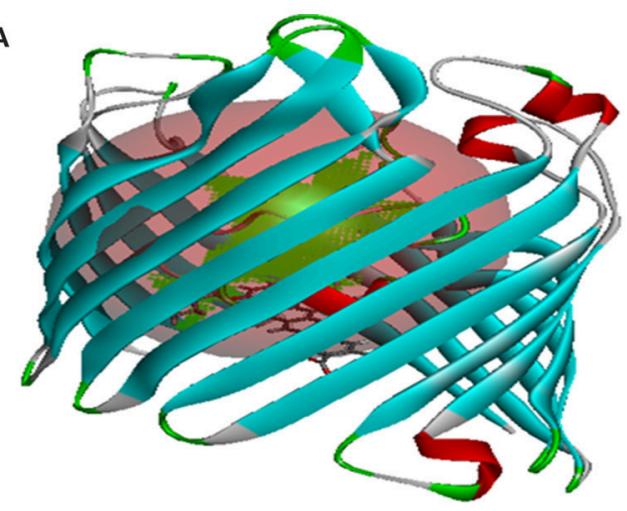

:

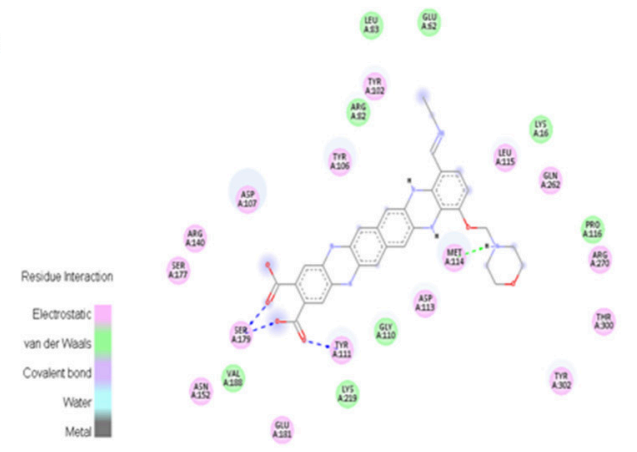

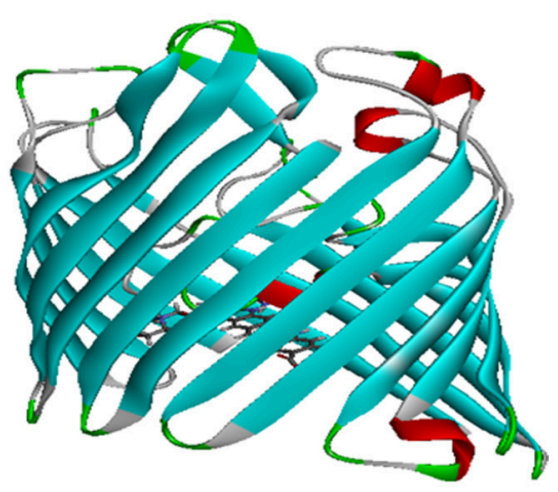

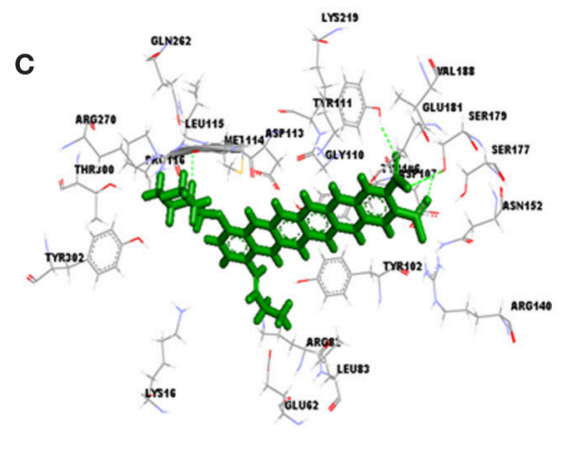

FIGURE 10 | In silico interaction between selected ligand (EMTAHDCA) and target OmpF porin protein (4GCQ). (A) Poses of docked complexes, green color in sphere indicates prominent active site where the ligand interacted, (B) 2D level interaction, (C) 3D level interaction.

A

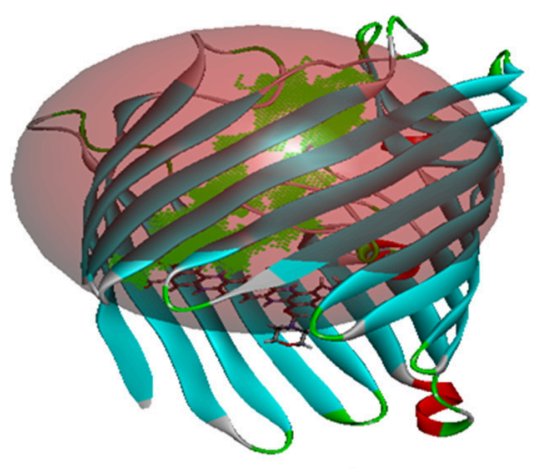

B

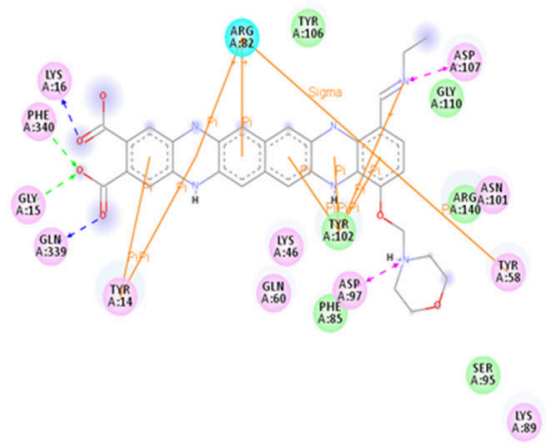

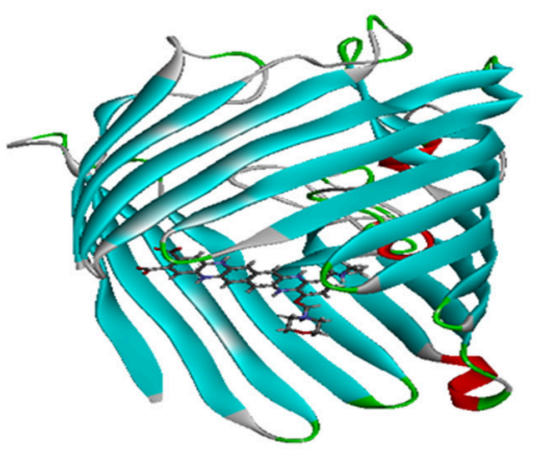

C

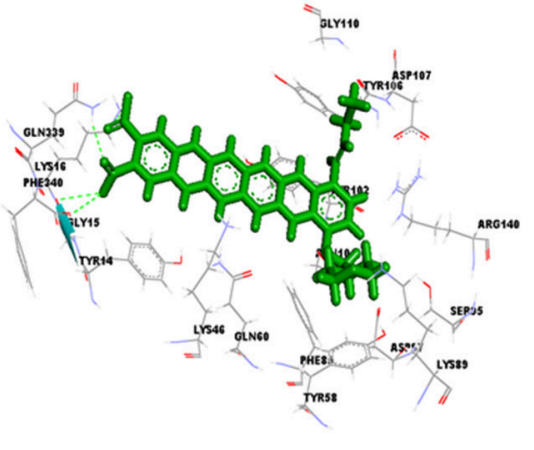

FIGURE 11 | In silico interaction between selected ligand (EMTAHDCA) and target OmpF porin protein (4GCS). (A) Poses of docked complexes, green color in sphere indicates prominent active site where the ligand interacted, (B) 2D level interaction, (C) 3D level interaction. 


\section{TLC and HPLC Analysis}

Thin layer chromatography (TLC) of the crude extract of cyanobacterium produced five bands A, B, C, D, E, and F (Figure 3). Only band E showed potent antibacterial property. Further band E was purified by HPLC, the individual peak with retention time (Rt) of $1.40 \mathrm{~min}$ (Figure 4 ) were collected.

\section{Antibacterial Bioassay}

This purified compound shows extensive antimicrobial activity against various gram negative bacterial strains chosen, such as Escherichia coli (KX758560), Proteus vulgaris (KX758561), and Pseudomonas aeruginosa (KX758562). Maximum zone of inhibition at a concentration of $150 \mu \mathrm{g} / \mathrm{mL}$ of pure compound isolated from Nostoc sp. MGL001 was observed viz. $11.15 \pm$ $0.117,10.17 \pm 0.235$, and $9.16 \pm 0.211 \mathrm{~mm}$ against Escherichia coli, Proteus vulgaris and Pseudomonas aeruginosa, respectively (Table 1). Upon further increasing the concentration upto $250 \mu \mathrm{g} / \mathrm{mL}$, no further increase in the size of zone was observed.

\section{ESI and NMR}

The obtained whitish powder compound was used for the analysis through ESI and NMR. The ${ }^{1} \mathrm{H}$ NMR $(500.30$ $\mathrm{MHz}$;) $\delta$ ppm w.r.t. DMSO-d $\mathrm{d}_{6}(2.500)$ (Figure 5) and ${ }^{13} \mathrm{C}\left\{{ }^{1} \mathrm{H}\right\}$ NMR $(125.80 \mathrm{MHz}) \delta \mathrm{ppm}$ w.r.t. DMSO-d 6 (39.51) (Figure 6) in $\mathrm{DMSO}-d_{6}$ at $25^{\circ} \mathrm{C}$ spectral data are given in Table 2. Therefore, on the basis of NMR, proposed structure of bioactive compound was 9-Ethyliminomethyl-12-(morpholin - 4 - ylmethoxy) -5, 8, 13, 16-tetraaza-hexacene - 2, 3- dicarboxylic acid (EMTAHDCA) (Figure 7). High resolution ESI-MS was operated in positive ion mode revealed an $\mathrm{m} / \mathrm{z}$ at 591.02 $\left(\mathrm{M}+\mathrm{H}^{+}\right)$corresponding to the molecular formula $\mathrm{C}_{32} \mathrm{H}_{26} \mathrm{~N}_{6} \mathrm{O}_{6}$ (Molecular weight-590.59) assigned in full agreement with NMR spectral data.

\section{Molecular Docking}

Molecular docking was successfully performed between selected ligand (EMTAHDCA) and target receptor RNA fragments (PDB ID: 1YRJ, 1MWL, 1J7T, and 1LC4) (Figure 8) and

TABLE 3 | Prominent active site residues identification of selected Omp porin protein models (4GCP, $4 G C Q$, and $4 G C S$ ).

\begin{tabular}{|c|c|c|c|}
\hline S.No. & Target & $\begin{array}{l}\text { PDB } \\
\text { ID }\end{array}$ & Common active site 1 residues \\
\hline 1. & $\begin{array}{l}\text { OmpF porin } \\
\text { protein }\end{array}$ & 4GCP & $\begin{array}{l}\operatorname{Arg}^{42}, \operatorname{Arg}^{82}, \operatorname{Tyr}^{32}, \operatorname{Leu}^{291}, \mathrm{Val}^{292}, \mathrm{Asn}^{293} \text {, } \\
\mathrm{Tyr}^{294}, \mathrm{Asn}^{316}, \mathrm{Il}^{318}, \mathrm{Val}^{326}, \mathrm{Asp}^{121}, \\
\mathrm{Gly}^{327}, \mathrm{Tyr}^{124}, \mathrm{PrO}^{239}, \mathrm{Il}^{240}, \mathrm{Thr}^{241}, \\
\mathrm{Phe}^{118}, \mathrm{Gly}^{119}, \mathrm{Gly}^{120}, \mathrm{Arg}^{167}, \mathrm{Glu}^{117}, \\
\mathrm{Ala}^{123}, \mathrm{Asp}^{113}, \mathrm{Arg}^{132}\end{array}$ \\
\hline 2. & & $4 G C Q$ & 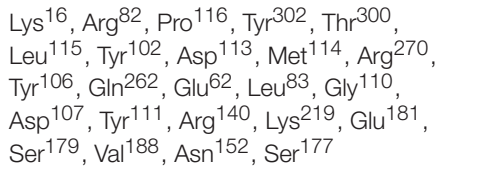 \\
\hline 3. & & 4GCS & $\begin{array}{l}\text { Lys }^{89}, \text { Ser }^{95}, \text { Arg }^{140}, \text { Tyr }^{58}, \text { Asp }^{97}, \text { Asp }^{107} \text {, } \\
\text { Phe } \\
\text { P5 }, \text { Asn }^{101}, \text { Gln }^{60}, \text { Tyr }^{106}, \text { Lys }^{46}, \text { Tyr }^{102} \text {, } \\
\text { Gly }\end{array}$ \\
\hline
\end{tabular}

OmpF porin protein (4GCP, 4GCQ, and 4GCS) (Figures 9, 10, 11) using YASARA software. The active site of OmpF was determined using Metapocket and results are represented in Table 3. Summary of molecular docking results of selected ligand with drug target RNA fragment and OmpF porin protein are represented in Table 4. The binding energy was found to be 000011.1450, 000010.0550, 000009.8620, and 000009.9690 for 1YRJ, 1MWL, 1J7T, and 1LC4 RNA fragments, respectively. Dissociation constant [pM] was found to be 00000000006770.2808 , 00000000042617.4336, 00000000059028.0117, and 00000000059028.0117 for 1YRJ, 1MWL, 1J7T, and 1LC4 RNA fragments, respectively (Table 4). Contacting receptor residues were identified through YASARA software and found that $\mathrm{G}^{\mathrm{A} 5}, \mathrm{U}^{\mathrm{A} 6}, \mathrm{~A}^{\mathrm{A} 8}, \mathrm{~A}^{\mathrm{A} 10}, \mathrm{~A}^{\mathrm{B} 33}, \mathrm{G}^{\mathrm{B} 39}$, and $\mathrm{U}^{\mathrm{A} 15}$ were common active site residues between reported $1 Y \mathrm{RJ}$ complex with Apramycin and selected ligand.

In case of $1 \mathrm{MWL}$ RNA fragment bases $\mathrm{C}^{\mathrm{A} 10}, \mathrm{C}^{\mathrm{A} 11}, \mathrm{G}^{\mathrm{A} 12}$, $\mathrm{G}^{\mathrm{A} 13}, \mathrm{U}^{\mathrm{A} 14}, \mathrm{C}^{\mathrm{A} 20}, \mathrm{G}^{\mathrm{B} 26}, \mathrm{U}^{\mathrm{B} 27}, \mathrm{C}^{\mathrm{B} 28}, \mathrm{C}^{\mathrm{B} 30}, \mathrm{~A}^{\mathrm{B} 31}, \mathrm{C}^{\mathrm{B} 32}, \mathrm{C}^{\mathrm{B} 33}$, and $\mathrm{G}^{\mathrm{B} 34}$ were involved in interaction between ligand and $1 \mathrm{MWL}$ RNA fragment, in which $\mathrm{G}^{\mathrm{B} 26}, \mathrm{U}^{\mathrm{B} 27}, \mathrm{C}^{\mathrm{B} 28}$, and $\mathrm{C}^{\mathrm{B} 30}$ bases were common active site residues between reported Geneticin antibiotic complex (1MWL) and ligand.

The ligand and 1J7T RNA fragment interacted with the following binding residues $\mathrm{C}^{\mathrm{A} 10}, \mathrm{C}^{\mathrm{A} 11}, \mathrm{G}^{\mathrm{A} 12}, \mathrm{G}^{\mathrm{A} 13}, \mathrm{U}^{\mathrm{A} 14}, \mathrm{G}^{\mathrm{A} 18}$, $\mathrm{U}^{\mathrm{A} 19}, \mathrm{C}^{\mathrm{A} 20}, \mathrm{C}^{\mathrm{B} 25}, \mathrm{G}^{\mathrm{B} 26}, \mathrm{U}^{\mathrm{B} 27}, \mathrm{C}^{\mathrm{B} 28}, \mathrm{~A}^{\mathrm{B} 29}, \mathrm{C}^{\mathrm{B} 30}, \mathrm{~A}^{\mathrm{B} 31}, \mathrm{C}^{\mathrm{B} 32}, \mathrm{C}^{\mathrm{B} 33}$, and $\mathrm{G}^{\mathrm{B} 34}$ in which $\mathrm{G}^{\mathrm{A} 18}, \mathrm{U}^{\mathrm{A} 19}, \mathrm{G}^{\mathrm{B} 26}, \mathrm{U}^{\mathrm{B} 27}, \mathrm{C}^{\mathrm{B} 28}, \mathrm{~A}^{\mathrm{B} 29}$, and $\mathrm{C}^{\mathrm{B} 30}$ bases were common between reported paromomycin antibiotic complex (1J7T) and ligand (Table 4).

Active site residues viz. $\mathrm{U}^{\mathrm{A} 15}, \mathrm{G}^{\mathrm{A} 16}, \mathrm{~A}^{\mathrm{A} 17}, \mathrm{~A}^{\mathrm{A} 18}, \mathrm{G}^{\mathrm{A} 19}, \mathrm{U}^{\mathrm{A} 20}$, $\mathrm{C}^{\mathrm{A} 21}, \mathrm{C}^{\mathrm{B} 27}, \mathrm{G}^{\mathrm{B} 28}, \mathrm{U}^{\mathrm{B} 29}, \mathrm{C}^{\mathrm{B} 30}, \mathrm{~A}^{\mathrm{B} 31}, \mathrm{C}^{\mathrm{B} 32}, \mathrm{~A}^{\mathrm{B} 33}$, and $\mathrm{C}^{\mathrm{B} 34}$ were involved in interaction with 1LC4 RNA fragment and ligand in which $\mathrm{G}^{\mathrm{A} 16}, \mathrm{~A}^{\mathrm{A} 18}, \mathrm{G}^{\mathrm{A} 19}, \mathrm{U}^{\mathrm{A} 20}, \mathrm{C}^{\mathrm{B} 27}, \mathrm{G}^{\mathrm{B} 28}, \mathrm{C}^{\mathrm{B} 30}$, and $\mathrm{A}^{\mathrm{B} 31}$ bases were common binding residues between reported tobramycin antibiotic complex (1LC4) and ligand.

In case of 4GCP porin protein docking results, site 1 residues $\mathrm{Tyr}^{32}, \operatorname{Arg}^{42}, \operatorname{Arg}^{82}, \mathrm{Asp}^{113}, \mathrm{Glu}^{117}, \mathrm{Phe}^{118}, \mathrm{Gly}^{119}, \mathrm{Gly}^{120}$, $\mathrm{Asp}^{121}, \mathrm{Ala}^{123}, \mathrm{Tyr}^{124}, \mathrm{Arg}^{132}, \mathrm{Arg}^{167}, \mathrm{Pro}^{239}, \mathrm{Ile}^{240}, \mathrm{Thr}^{241}$, $\mathrm{Leu}^{291}, \mathrm{Val}^{292}, \mathrm{Asn}^{293}, \mathrm{Tyr}^{294}, \mathrm{Asn}^{316}, \mathrm{Il}^{318}, \mathrm{Val}^{326}$, and $\mathrm{Gly}^{327}$ were involved in interaction with good positive energies and dissociation constant. The site 1 is the major prominent site for interaction of any compound. The residues of site $1\left(\mathrm{Tyr}^{32}\right.$, $\mathrm{Phe}^{118}, \mathrm{Gly}^{119}, \mathrm{Gly}^{120}, \mathrm{Asp}^{121}, \mathrm{Tyr}^{124}$, Leu ${ }^{291}, \mathrm{Val}^{292}, \mathrm{Asn}^{316}$, and $\mathrm{Val}^{326}$ ) are common to the reported active site known against ampicillin antibiotics (Figure 9, Table 4). The 2D and 3D view of interacted residues also mentioned in Figure 9. In residue interaction electrostatic bond, van der waals, covalent bond and hydrogen bond were involved.

Molecular docking between 4GCQ porin protein and ligand indicates that active site 1 residues $\mathrm{Lys}^{16}, \mathrm{Glu}^{62}, \mathrm{Arg}^{82}, \mathrm{Leu}^{83}$, $\mathrm{Tyr}^{102}, \mathrm{Tyr}^{106}, \mathrm{Asp}^{107}, \mathrm{Gly}^{110}, \mathrm{Tyr}^{111}, \mathrm{Asp}^{113}, \mathrm{Met}^{114}$, Leu ${ }^{115}$, Pro ${ }^{116}, \mathrm{Glu}^{181}, \mathrm{Val}^{188}, \mathrm{Lys}^{219}, \mathrm{Gln}^{262}, \mathrm{Arg}^{270}, \mathrm{Thr}^{300}$, and $\mathrm{Tyr}{ }^{302}$ were involved in interaction, whereas only $\mathrm{Arg}^{82}$ are common to the reported active site known against Carbenicillin antibiotics (Figure 10, Table 4). The electrostatic bond, van der waals, covalent bond and hydrogen bond were involved in residues interaction could be clearly visible in $2 \mathrm{D}$ and $3 \mathrm{D}$ view in Figure 10. 
TABLE 4 | Summary of molecular docking results of selected ligand with drug target RNA fragment and OmpF porin protein.

\begin{tabular}{|c|c|c|c|c|c|c|c|c|}
\hline S.No. & Ligand & Target & $\begin{array}{l}\text { PDB } \\
\text { ID }\end{array}$ & $\begin{array}{l}\text { Binding } \\
\text { energy } \\
\text { [kcal/mol] }\end{array}$ & $\begin{array}{l}\text { Dissociation } \\
\text { constant [pM] }\end{array}$ & $\begin{array}{l}\text { Contacting } \\
\text { receptor residues }\end{array}$ & $\begin{array}{l}\text { Reported active site } \\
\text { residues }\end{array}$ & Common \\
\hline 2. & EMTAHDCA & $\begin{array}{l}\text { RNA } \\
\text { Fragment }\end{array}$ & $1 \mathrm{MWL}$ & 000010.0550 & 00000000042617.4336 & $\begin{array}{l}C^{A 10}, C^{A 11}, G^{A 12}, \\
G^{A 13}, \cup^{A 14}, C^{A 20}, \\
G^{B 26}, U^{B 27}, C^{B 28}, \\
C^{B 30}, A^{B 31}, C^{B 32}, \\
C^{B 33}, G^{B 34}\end{array}$ & $\begin{array}{l}A^{B 33}, G^{B 39}, G^{A 4}, \cup^{A 5}, \\
A^{A 6}, C^{A 7}, C^{A 7}, C^{A 8}, \\
G^{A 15}, A^{A 16}, A^{A 17}, \\
G^{A 18}, \cup^{A 19}, C^{B 25}, \\
G^{B 26}, \cup^{B 27}, C^{B 28}, \\
A^{B 29}, C^{B 30}, G^{B 37}, \\
A^{B 38}, A^{B 39}, G^{B 40}, \\
U^{B 41}\end{array}$ & $\begin{array}{l}G^{B 26}, \cup^{B 27} \\
C^{B 28}, C^{B 30}\end{array}$ \\
\hline 3. & EMTAHDCA & $\begin{array}{l}\text { RNA } \\
\text { Fragment }\end{array}$ & $1 \mathrm{J7T}$ & 000009.8620 & 00000000059028.0117 & $\begin{array}{l}C^{A 10}, C^{A 11}, G^{A 12}, \\
G^{A 13}, \cup^{A 14}, G^{A 18}, \\
U^{A 19}, C^{A 20}, C^{B 25}, \\
G^{B 26}, \cup^{B 27}, C^{B 28}, \\
A^{B 29}, C^{B 30}, A^{B 31}, \\
C^{B 32}, C^{B 33}, G^{B 34}\end{array}$ & $\begin{array}{l}G^{A 4}, \cup^{A 5}, C^{A 6}, A^{A 7}, \\
\cup^{A 17}, G^{A 15}, A^{A 16}, \\
A^{A 17}, G^{A 18}, \cup^{A 19}, \\
G^{B 26}, \cup^{B 27}, C^{B 28}, \\
A^{B 29}, C^{B 30}, \cup^{B 36}, \\
G^{B 37}, A^{B 38}, A^{B 39}, \\
G^{B 40}\end{array}$ & $\mathrm{G}^{\mathrm{A} 18}, \mathrm{U}^{\mathrm{A} 19}$ \\
\hline 4. & EMTAHDCA & $\begin{array}{l}\text { RNA } \\
\text { Fragment }\end{array}$ & 1LC4 & 000009.9690 & 00000000049274.9414 & $\begin{array}{l}U^{\mathrm{A} 15}, G^{\mathrm{A} 16}, \mathrm{~A}^{\mathrm{A} 17}, \\
\mathrm{~A}^{\mathrm{A} 18}, \mathrm{G}^{\mathrm{A} 19}, \cup^{\mathrm{A} 20}, \\
\mathrm{C}^{\mathrm{A} 21}, \mathrm{C}^{\mathrm{B} 27}, \mathrm{G}^{\mathrm{B} 28}, \\
\mathrm{U}^{\mathrm{B} 29}, \mathrm{C}^{\mathrm{B} 30}, \mathrm{~A}^{\mathrm{B} 11}, \\
\mathrm{C}^{\mathrm{B} 32}, \mathrm{~A}^{\mathrm{B} 33}, \mathrm{C}^{\mathrm{B} 34}\end{array}$ & $\begin{array}{l}C^{A 4}, G^{A 5}, C^{A 7}, G^{A 16}, \\
A^{A 18}, G^{A 19}, \cup^{A 20}, \\
C^{B 27}, G^{B 28}, C^{B 30}, \\
A^{B 31}, G^{B 39}, A^{B 41}, \\
G^{B 42}, \cup^{B 43}\end{array}$ & $\begin{array}{l}\mathrm{G}^{\mathrm{A} 16}, \mathrm{~A}^{\mathrm{A} 18}, \\
\mathrm{G}^{\mathrm{A} 19}, \mathrm{U}^{\mathrm{A} 20} \\
\mathrm{C}^{\mathrm{B} 27}, \mathrm{G}^{\mathrm{B} 28}, \\
\mathrm{C}^{\mathrm{B} 30}, \mathrm{~A}^{\mathrm{B} 31}\end{array}$ \\
\hline 6. & EMTAHDCA & $\begin{array}{l}\text { OmpF porin } \\
\text { protein }\end{array}$ & $4 \mathrm{GCQ}$ & 000009.9500 & 00000000050880.7266 & 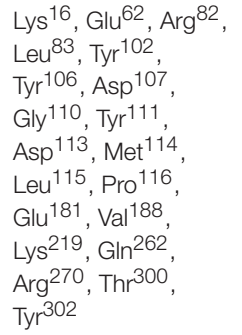 & $\begin{array}{l}\mathrm{Tyr}^{22}, \mathrm{Tyr}^{32}, \mathrm{Gly}^{33}, \\
\text { Arg }^{42}, \mathrm{Arg}^{82}, \mathrm{Glu}^{117} \\
\mathrm{Phe}^{118}, \mathrm{Gly}^{119}, \mathrm{Gly}^{120} \\
\text { Asp121 } \text { Arg }^{132}, \mathrm{Val}^{292}\end{array}$ & $\operatorname{Arg}^{82}$ \\
\hline 7. & EMTAHDCA & $\begin{array}{l}\text { OmpF porin } \\
\text { protein }\end{array}$ & $4 G C S$ & 000008.6880 & 00000000428165.4063 & $\begin{array}{l}\text { Tyr }^{14}, \text { Gly }^{15}, \text { Lys }^{16}, \\
\text { Lys }^{46}, \text { Tyr }^{58}, \text { Gln }^{60} \\
\text { Phe }^{85}, \text { Lys }^{89}, \text { Ser }^{95} \\
\text { Asp }^{97}, \text { Asn }^{101} \text {, } \\
\text { Tyr }^{102}, \text { Tyr }^{106} \text {, } \\
\text { Asp }^{107}, \text { Gly }^{110} \\
\text { Arg }^{140}, \text { Gln }^{339}, \\
\text { Phe }^{340}\end{array}$ & $\operatorname{Thr}^{165}, \operatorname{Arg}^{168}, \mathrm{Ser}^{248}$ & \\
\hline
\end{tabular}


Active site 1 residues involved in interaction were $\mathrm{Phe}^{85}, \mathrm{Ser}^{95}$, Asn ${ }^{101}, \mathrm{Tyr}^{102}, \mathrm{Tyr}^{106}, \mathrm{Gly}^{110}$, and $\mathrm{Arg}^{140}$ in case of $4 \mathrm{GCS}$ porin protein and ligand docking through van der waals bonding, Residues like Tyr ${ }^{14}, \mathrm{Lys}^{16}, \mathrm{Gly}^{15}, \mathrm{Phe}^{34}, \mathrm{Gly}^{15}, \mathrm{Gln}^{339}, \mathrm{Asp}^{97}$, Lys $^{46}, \mathrm{Lys}^{89}{ }^{8} \mathrm{Tyr}^{58}, \mathrm{Asn}^{101}$, and Asp ${ }^{107}$ involved in electrostatic bonding whereas $\mathrm{Arg}^{82}$ involved in hydrogen bond interaction (Figure 11, Table 4).

\section{DISCUSSION}

Cyanobacteria are known to produce a wide variety of biologically active compounds. To the best of our knowledge, this type of new bioactive compound EMTAHDCA is first time reported from fresh water cyanobacterium Nostoc sp. MGL001. In order to isolate EMTAHDCA various chromatographic techniques were tested but TLC was found to be most useful tool to achieve the separation of complex mixtures of organic molecules. Competition between solute and the mobile phase is responsible for the separation of compounds through TLC (Kumar et al., 2013). In order to separate unknown bioactive compounds, different gradients of solvents were tested and ultimately carbon tetrachloride: methanol in 9:1 ratio was found to be best for separation point of view. Same solvent composition was also used by Srivastava et al. (2015) to separate bioactive compound from fresh water cyanobacteria Geitlerinema sp. CCC728 and Arthrospira sp. CCC729.

Liquid chromatography is one of the most efficient and powerful separation methods for the preparative purification and isolation of biological substances (Nikitas and Pappa-Louisi,
2009). A number of different chromatographic methods were considered for purification of bioactive compounds but reason behind selection of HPLC technique was its reproducibility, sensitivity, high resolution, and absence of extensive sample preparation or derivatization (Quilliam, 2003; Snyder and Dolan, 2006). Water is the weakest eluent for reverse phase HPLC so; its eluent strength is then modified by adding methanol or acetonitrile which are less polar but miscible solvents. After testing methanol and acetonitrile based systems acetonitrile was selected as mobile phase because it gave better peak shapes, stable baselines and sharper resolution as compared to methanol.

The use of ESI-MS systems when coupled with a HPLCsystem increases their selectivity and benefits from both techniques (Vishwakarma and Rai, 2013). For the structure elucidation of newly isolated compounds NMR methods have been used as it is very much capable of elucidating intact biomaterials nondestructively without any preceding derivatization (Willmann et al., 2011). Due to the simplicity of sample preparation and ease of interpretation of characteristic signals, NMR was favored as natural products are closely related and difficult to separate. The ${ }^{1} \mathrm{H}$ and ${ }^{13} \mathrm{C}\left\{{ }^{1} \mathrm{H}\right\}$ NMR spectral data of EMTAHDCA has already been presented and interpreted in result section. The proton NMR spectrum of the EMTAHDCA (Figure 5), as per the structure, is expected to show a broad peak at $\delta 11.979$ (due to presence two acidic proton of $-\mathrm{COOH}$ groups), two doublet [at $\delta 7.899-7.872$ (due to presence of one aromatic proton, such as $\mathrm{C}_{10} \underline{\mathrm{H}}$ ) and at $\delta 7.141-7.127$ (due to presence of one aromatic proton, such as $\mathrm{C}_{11} \underline{\mathrm{H}}$ )], four singlet [at $\delta 8.935$ (due to presence of one proton $-\mathrm{N}=\mathrm{CH}$ group), $\delta$

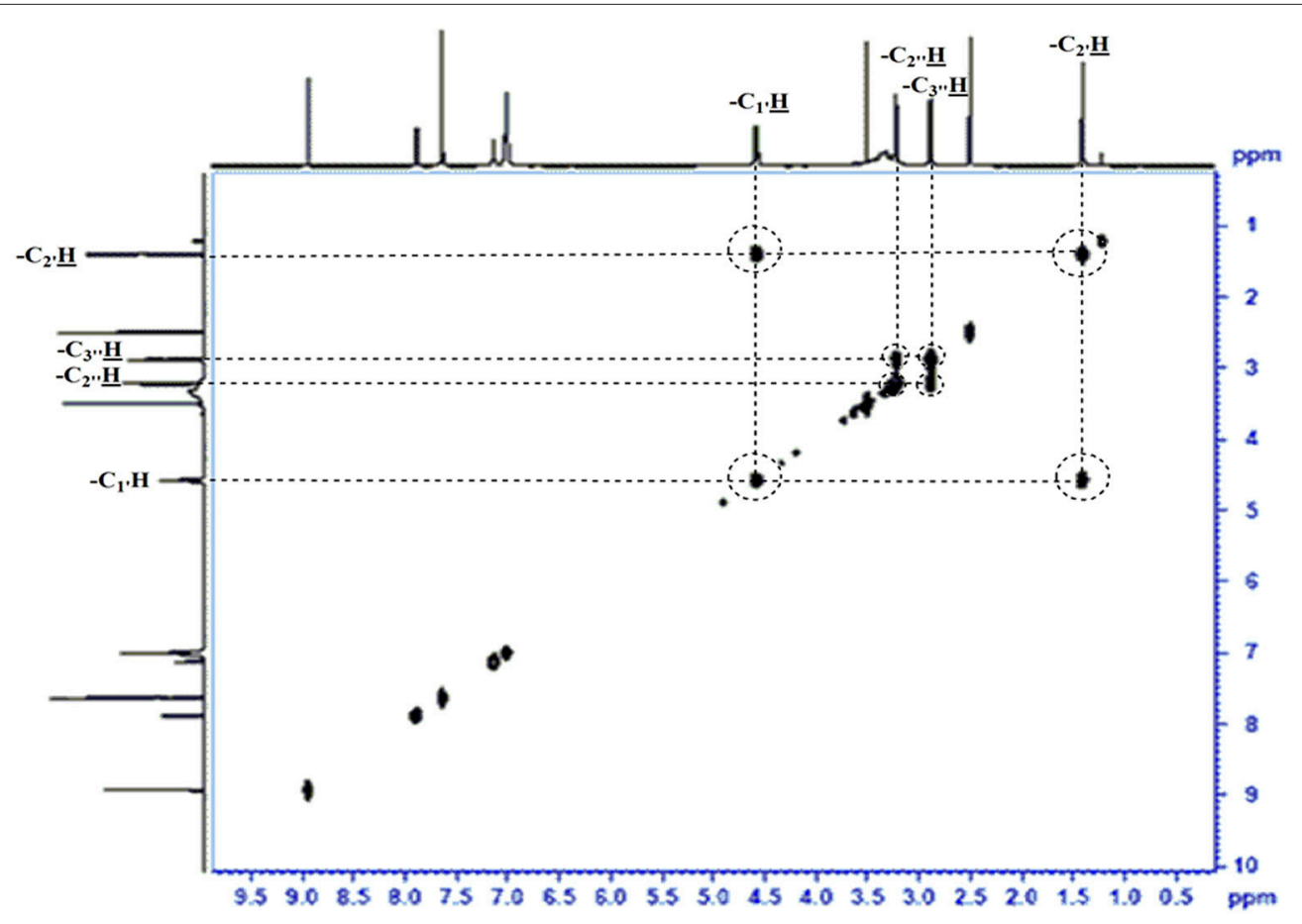

FIGURE 12 | H-H COSY NMR spectrum of EMTAHDCA. 
7.635 (due to presence of two aromatic protons, such as $\mathrm{C}_{1} \underline{\mathrm{H}}$ and $\mathrm{C}_{4} \underline{\mathrm{H}}$ ), $\delta 7.010$ (due to presence of four aromatic protons, such as $\mathrm{C}_{6} \mathrm{H}, \mathrm{C}_{7} \mathrm{H}, \mathrm{C}_{14} \mathrm{H}$, and $\mathrm{C}_{15} \mathrm{H}$ ) and at $\delta 3.505$ (due to presence of two protons of methylene group, such as $\left.\mathrm{C}_{5^{\prime \prime}} \underline{\mathrm{H}}\right)$ ], one quartet at $\delta$ 4.601-4.558 (due to presence of two protons of methylene group, such as $\mathrm{C}_{1^{\prime}} \underline{\mathrm{H}}$ ) and three triplets [at $\delta$ $3.232-3.213$ (due to presence of two protons of methylene group, such as $\mathrm{C}_{2^{\prime \prime}} \underline{\mathrm{H}}$ ), $\delta$ 2.894-2.875(due to presence of two proton of methylene group, such as $\mathrm{C}_{3^{\prime \prime}} \underline{\mathrm{H}}$ ) and at $\delta 1.425-1.396$ (due to presence of three protons of methyl group, such as $\mathrm{C}_{2^{\prime}} \underline{\mathrm{H}}$ )]. The splitting pattern of different type of protons of aliphatic region also confirmed by $\mathrm{H}-\mathrm{H}$ COSY spectrum (Figure 12), in this spectrum the methylene group protons $\left(\mathrm{C}_{1^{\prime}} \underline{\mathrm{H}}\right)$ coupled with the methyl group protons $\left(\mathrm{C}_{2^{\prime}} \underline{\mathrm{H}}\right)$ and other methylene group protons $\left(\mathrm{C}_{2^{\prime}} \underline{\mathrm{H}}\right)$ coupled with another methylene group protons $\left(\mathrm{C}_{3^{\prime}} \underline{\mathrm{H}}\right)$. In the ${ }^{13} \mathrm{C}\left\{{ }^{1} \mathrm{H}\right\}$ NMR spectrum (Figure 6), 19 carbon signals were observed, including carbonyl carbon $(\delta$ $176.08)$, one imine carbon ( $\delta$ 148.31), four aromatic carbons ( $\delta 137.20,111.14,110.96$, and 105.43), eight different type quaternary aromatic carbons $(\delta 166.05,153.84,151.86,146.00$, $145.92,135.05,118.96$, and 107.02), four different type methylene carbons $(\delta 69.73,50.78,48.95$, and 45.34$)$, and one methyl carbon ( $\delta$ 14.22). The different type of carbon interpreted with help of DEPT-90 and DEPT-135 NMR spectral technique, in DEPT-135 spectrum (Figure 13), carbon with one hydrogen (four type aromatic carbons and one imine carbon) and three hydrogens (one methyl carbon) shows positive peak, whereas carbon has two hydrogens (four different type of methylene carbons) shows negative peak and in DEPT-90 spectrum (Figure 14), carbon with one hydrogen (four type aromatic carbons and one imine carbon) shows only positive peak. The spectrum consists of all the expected signals as shown in spectral data of NMR section. The predicted structure of EMTAHDCA using ESI-MS and NMR spectra were verified by subjecting predicted structure on Pubchem (https://pubchem.ncbi.nlm.nih.gov/) and PubMed NCBI https://www.ncbi.nlm.nih.gov/pubmed) and by comparing experimental data with published literature on bioactive compounds of cyanobacteria but structure of EMTAHDCA clearly indicated that it is a novel compound that was not reported earlier in any literature or natural product database.

The ESI-MS and NMR spectra were verified by comparing experimental data with published literature on bioactive compounds but structure of EMTAHDCA clearly indicated that it is a novel compound that was not reported in literature or natural product database.

Also EMTAHDCA identified as an antibacterial agent through in vitro and in silico approaches. The present work based on in silico preclinical evaluation of novel isolated compound EMTAHDCA to proceed ahead for further drug trials. Structure elucidation of bioactive compound EMTAHDCA (Ethyliminomethyl-12-(morpholin - 4 - ylmethoxy) -5, 8, 13, 16 tetraaza - hexacene - 2, 3 dicarboxylic acid) was done through NMR already mentioned in results section. This compound contain morpholin moiety that is rare in nature. The 2hydroxymorpholine moiety was also observed in bacilosarcins A isolated from marine-derived bacterium Bacillus subtilis TPB0611 showed growth inhibition against barnyard millet (Azumi

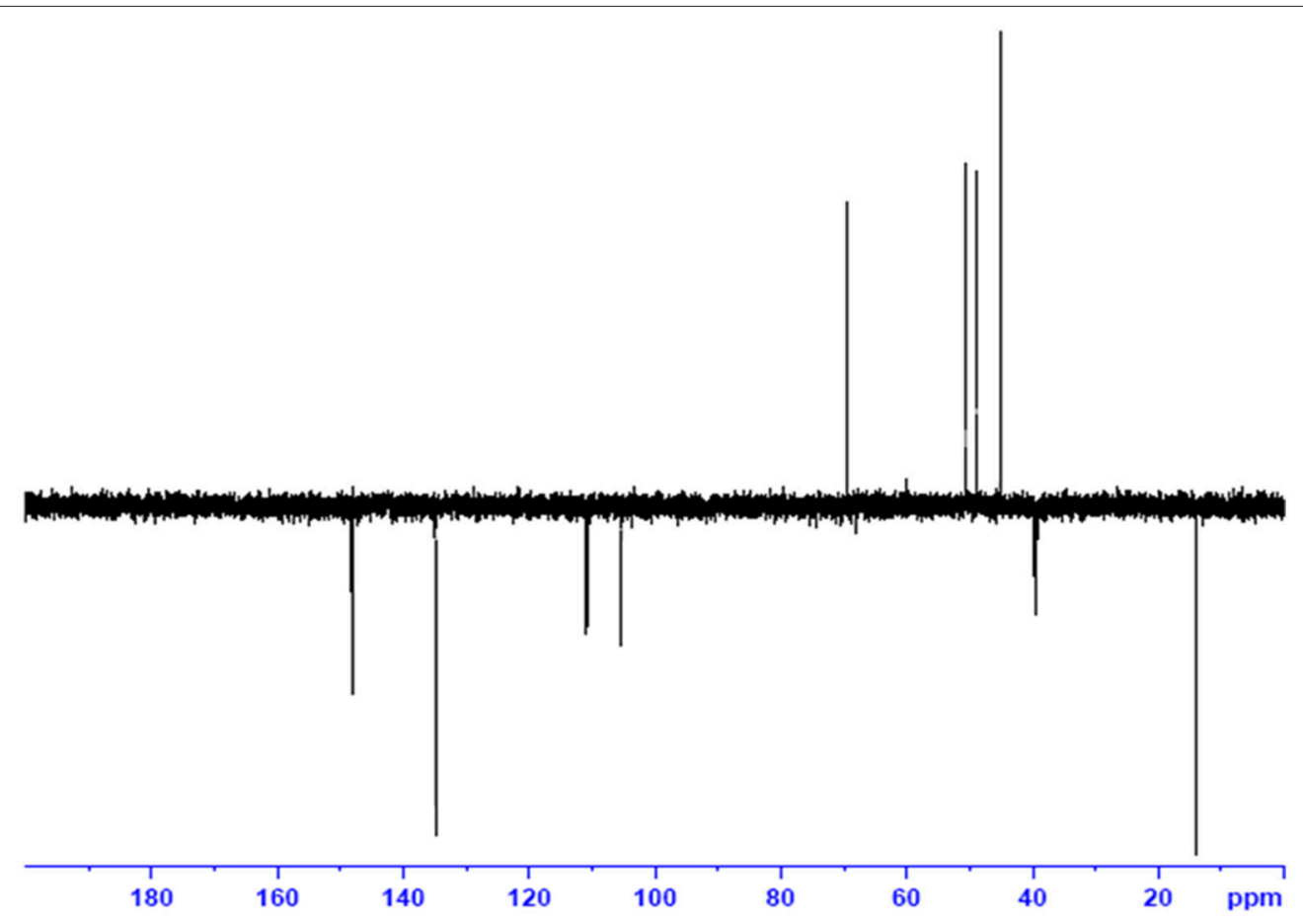

FIGURE 13 | DEPT-135 NMR spectrum of EMTAHDCA. 


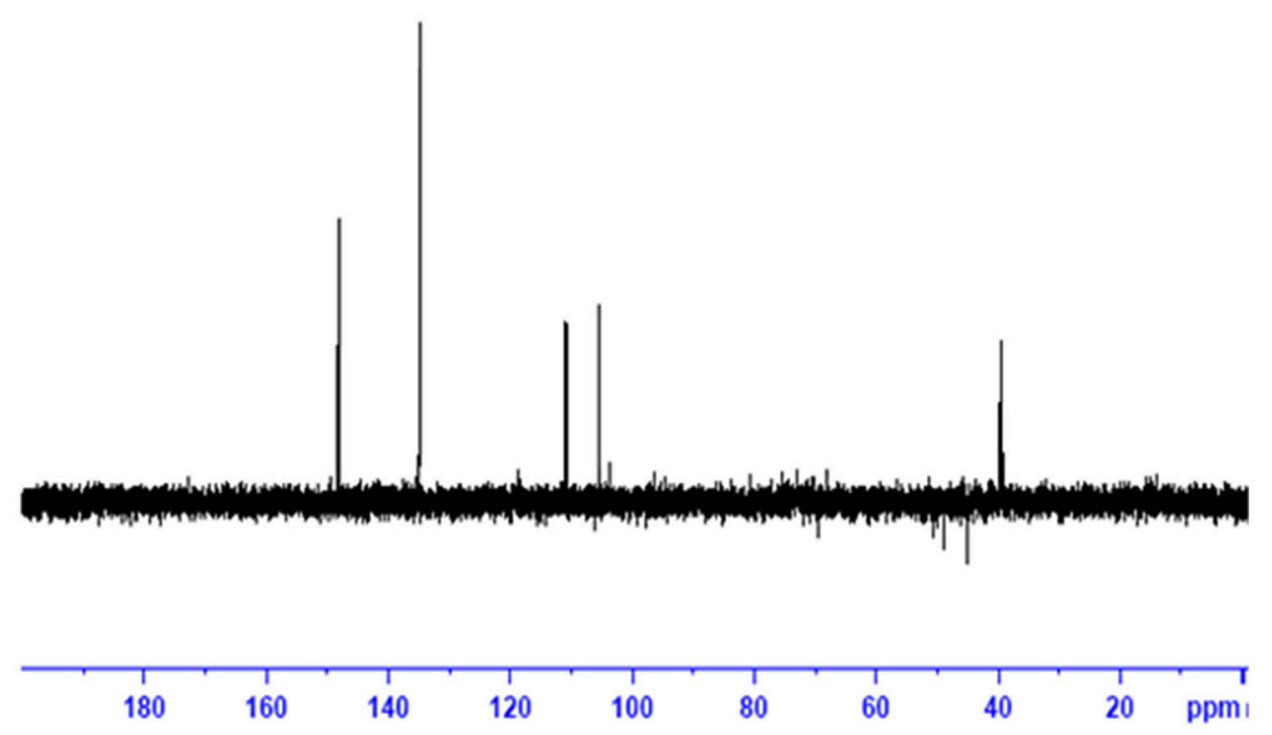

FIGURE 14 | DEPT-90 NMR spectrum of EMTAHDCA.

et al., 2008). Morpholin is commonly used in organic synthesis. It acts as a building block in the preparation of the anticancer agent gefitinib (Iressa), the antibiotic linezolid and the analgesic dextromoramide (Fung et al., 2001; McKillop et al., 2005). Presence of morpholin moiety in the bioactive compound EMTAHDCA is likely to be responsible for its antibiotic activity. Pure bioactive compound EMTAHDCA $(150 \mu \mathrm{g} / \mathrm{mL})$ possessed antibacterial activity against gram negative bacterial strains viz. E. coli, P. vulgaris, and $P$. aeruginosa. These strains were tested in laboratory and found multi drug resistant (MDR) to erythromycin, imipenem, ciprofloxacin and vancomycin (data not shown). Bacterial adaptation to antibiotics generated serious medical problem (Chalasani et al., 2015). This finding gives an idea that EMTAHDCA compound could be used as an alternative antibiotic against such resistant bacterial strains. In order to prove its antibiotic potential in silico technique was performed to know the interaction of selected bioactive compound EMTAHDCA with small ribosomal subunit (30S) (PDBID: 1YRJ, 1MWL, 1J7T, and 1LC4) fragment and OmpF porin protein (PDBID: 4GCP, 4GCQ, and 4GCS).

Protein synthesis is a fundamental process performed by ribosome. More than half of the total number of clinically used antibiotics exerts their antibiotic effects on the bacterial ribosomes by binding to several sites of 30 and $50 \mathrm{~S}$ subunits ultimately blocking protein synthesis (Franceschi and Duffy, 2006). Both the $30 \mathrm{~S}$ and the $50 \mathrm{~S}$ ribosomal subunits provide functionally relevant active site pockets considered as ribofunctional loci where antibiotics do act (Wilson, 2014). The ribosomes are highly conserved organelles having precise conformational variation which facilitates drug selectivity for clinical use (Hermann, 2005).

The outer membrane (OM), unique to gram negative bacteria acts as selective barrier by providing an extra protective layer against a harsh environment. OM provides passage for nonspecific charged and zwitterionic nutrient molecules (Delcour, 2009). Three major general diffusion porins found in E.coli are $\mathrm{OmpF}, \mathrm{OmpC}$, and $\mathrm{PhoE}$. In several reports, loss of $\mathrm{OmpF}$, and $\mathrm{OmpC}$ porins are linked to antibiotic resistance, especially for Escherichia coli and Salmonella typhimurium (Nikaido, 2003). Therefore, a better understanding of how modification of membrane permeability triggers bacterial resistance to antibiotics is necessary for the development of new antibiotic therapy strategies.

Molecular docking calculation between EMTAHDCA and target receptor molecule (RNA fragment) showed good binding affinity with best positive energies for selected compound EMTAHDCA. More positive energies indicates stronger binding, and negative energies mean no binding (Krieger and Vriend, 2014). Bases involved in interaction between ligand and ribosomal fragment resides at the prominent active site of ribosomal fragment. Similar type of interaction was observed in the case of EMTAHDCA docking with OmpF porin protein. The crystal structures of $\mathrm{OmpF}$ in complex with ampicillin, carbenicillin and ertapenem (4GCP, 4GCQ, and 4GCS) have been already reported. Residues involved in interaction between selected ligand and $\mathrm{OmpF}$ porin proteins was found in prominent active site (site 1) predicted by Metapocket. Therefore, with the help of emerging molecular docking tools, we could able to prove that isolated compound EMTAHDCA have ability to work as an antibiotic agent and also recognize their precise mode of action against targeted host. This study suggested that selected compound EMTAHDCA could better act in comparison with reported antibiotics and able to serve as clinical candidate.

\section{CONCLUSION}

Novel bioactive compound EMTAHDCA isolated from Nostoc sp. MGL001 has antibacterial activity against multi drug resistant 
bacterial strains viz. E coli, $P$ vulgaris, and $P$ aeruginosa through in vitro and in silico studies. Therefore, it is worth mentioning that EMTAHDCA could serve as potential antibiotic drug.

\section{AUTHOR CONTRIBUTIONS}

Niveshika and AM designed the experiments. Niveshika performed the experiments. Niveshika, EV, AM, AS, and VS analyzed the data. Niveshika and EV wrote the manuscript and AM critically reviewed the paper.

\section{REFERENCES}

Azumi, M., Ogawa, K., Fujita, T., Takeshita, M., Yoshida, R., Furumai, T., et al. (2008). Bacilosarcins A and B, novel bioactive isocoumarins with unusual heterocyclic cores from the marine-derived bacterium Bacillus subtilis. Tetrahedron 64, 6420-6425. doi: 10.1016/j.tet.2008.04.076

Berdy, J. (2005). Bioactive microbial metabolites. J. Antibiot. 58, 1-26. doi: $10.1038 /$ ja.2005.1

Bullerjahn, G. S., and Post, A. F. (2014). Physiology and molecular biology of aquatic cyanobacteria. Front. Microbiol. 5:359. doi: 10.3389/fmicb.2014.00359

Burja, A. M., Banaigs, B., Abou-Mansour, E., Burgess, J. G., and Wright, P. C. (2001). Marine cyanobacteria-a prolific source of natural products. Tetrahedron 57, 9347-9377. doi: 10.1016/S0040-4020(01)00931-0

Chalasani, A. G., Dhanarajan, G., Nema, S., Sen, R., and Roy, U. (2015). An antimicrobial metabolites from Bacillus sp.: significant activity against pathogenic bacteria including multidrug resistant clinical strains. Front. Microbiol. 6:1335. doi: 10.3389/fmicb.2015.01335

Clardy, J., and Walsh, C. (2004). Lessons from natural molecules. Nature 432, 829-837. doi: 10.1038/nature03194

Cragg, G. M., and Newman, D. J. (2013). Natural products: a continuing source of novel drug leads. Biochim. Biophys. Acta 1830, 3670-3695. doi: 10.1016/j.bbagen.2013.02.008

Delcour, A. H. (2009). Outer membrane permeability and antibiotic resistance. Biochim. Biophys. Acta 1794, 808-816. doi: 10.1016/j.bbapap.2008.11.005

Dembitsky, V. M., and Rezanka, T. (2005). Metabolites produced by nitrogen fixing Nostoc species. Folia Microbiol. (Praha). 50, 363-391. doi: 10.1007/BF02931419

Desikachary, T. V. (1959). Cyanophyta. New Delhi: Indian Council of Agricultural Research 700.

Dias,. E., Oliveira, M., Jones-Dias, D., Vasconcelos, V., Ferreira, E., Manageiro, V., et al. (2015). Assessing the antibiotic susceptibility of freshwater Cyanobacteria spp. Front. Microbiol. 6:799. doi: 10.3389/fmicb.2015.00799

Doan, N. T., Rickards, R. W., Rothschild, J. M., and Smith, G. D. (2000). Allelopathic actions of alkaloids 12-epi-hapalindole $\mathrm{E}$ isonitrile and calothrixin A from cyanobacteria of the genera Fischerella and Calothrix. J. Appl. Phycol. 12, 409-416. doi: 10.1023/A:1008170007044

Dodds, W. K., Gudder, D. A., and Mollenhauer, D. (1995). The ecology of Nostoc. J. Phycol. 31, 2-18. doi: 10.1111/j.0022-3646.1995.00002.x

El-Elimat, T., Zhang, X., Jarjoura, D., Moy, F. J., Orjala, J., Kinghorn, A. D., et al. (2012). Diversity of Metabolites from Fungi, Cyanobacteria, and Plants Relative to FDA-approved anticancer agents. ACS Med. Chem. Lett. 3, 645-649. doi: $10.1021 / \mathrm{ml} 300105 \mathrm{~s}$

Franceschi, F., and Duffy, E. M. (2006). Structure based drug design meets the ribosome. Biochem. Pharmacol. 71, 1016-1025. doi: 10.1016/j.bcp.2005.12.026

Fung, H. B., Kirschenbaum, H. L., and Ojofeitimi, B. O. (2001). Linezolid: an oxazolidinone antimicrobial agent. Clin. Ther. 23, 356-391. doi: 10.1016/S0149-2918(01)80043-6

Gao, Y. D., and Huang, J. F. (2011). An extension strategy of Discovery Studio 2.0 for non-bonded interaction energy automatic calculation at the residue level (in Chinese). Zool. Res. 32, 262-266. doi: 10.3724/SP.J.1141.2011.03262

Gul, W., and Hamam, M. J. (2005). Indole alkaloid marine natural products: an established source of cancer drug leads with considerable promise for the

\section{ACKNOWLEDGMENTS}

The Head and coordinator CAS, Department of Botany, Banaras Hindu University, Varanasi, India is gratefully acknowledged for providing laboratory facilities. We are thankful to Central Instrumentation Facility, Department of Botany BHU for HPLC. We are grateful to Indian Institute of Technology (IIT) Central Instrumentation Facility, BHU for NMR. We are also grateful to Interdisciplinary School of Life Sciences (ISLS), BHU for ESIMS. Two of us (Niveshika and EV) are thankful to the UGC, New Delhi for financial support in the form of JRF.

control of parasitic, neurological and other diseases. Life Sci. 78, 442-453. doi: 10.1016/j.lfs.2005.09.007

Han, Q., Zhao, Q., Fish, S., Simonsen, K. B., Vourloumis, D., Froelich, J. M., et al. (2005). Molecular recognition by glycoside pseudo base pairs and triples in an apramycin-RNA complex. Angew. Chem. Int. Ed Engl. 44, 2694-2700. doi: 10.1002/anie.200500028

Harada, K. I., Kondo, F., and Lawton, L. (1999). "Laboratory analysis of cyanotoxins," in Toxic Cyanobacteria in Water, eds I. Chorus and J. Bartram ( London: E \& F.N Spoon and WHO), 369-405.

Hermann, T. (2005). Drugs targeting the ribosome. Curr. Opin. Struct. Biol. 15, 355-366. doi: 10.1016/j.sbi.2005.05.001

Hirata, K., Yoshitomi, S., Dwi, S., Iwabe, O., Mahakhant,. A., Polchai, J., et al. (2003). Bioactivities of nostocine A produced by a freshwater cyanobacterium Nostoc spongiaeforme TISTR 8169. J. Biosci. Bioeng. 95, 512-517. doi: 10.1016/S1389-1723(03)80053-1

Huang, B. (2009). MetaPocket: a meta approach to improve protein ligand binding site prediction. OMICS 13, 325-330. doi: 10.1089/omi. 2009.0045

Jaki, B., Orjala, J., and Sticher, O. (1999). A novel extracellular diterpenoid with antibacterial activity from the Cyanobacterium Nostoc commune. J. Nat. Prod. 62, 502-503. doi: 10.1021/np980444x

Karchmer, A. W. (2004). Increased antibiotic resistance in respiratory tract pathogens: PROTEKT US- an update. Clin. Infect. Dis. 39, 142-150. doi: $10.1086 / 421352$

Khairy, H. M., and El-Kassas, H. Y. (2010). Active substance from some blue green algal species used as antimicrobial agents. Afr. J. Biotechnol. 9, 2789-2800. doi: 10.5897/AJB2010.000-3104

Kim, J. D., and Lee, C. G. (2006). Diversity of heterocystous filamentous cyanobacteria (blue-green algae) from rice paddy fields and their differential susceptibility to ten fungicides used in Korea. J. Microbiol. Biotechnol. 16, 240-246.

Kobayashi, A., Kajiyama, S., Inawaka, K., Kanzaki, H., and Kawazu, K. (1994). Nostodione, A. A novel mitotic spindle poison from a blue-green alga Nostoc commune. J. Biosci. 49, 464-470.

Komarek, J. (2013). “Cyanoprokaryota. 3. Heterocytous genera," in Suswasserflora von Mitteleuropa/Freshwater flora of Central Europe, ed B. Budel, G. Gartner, L. Krienitz, and M. Schagerl (Heidelberg: Springer Spektrum), 1130.

Krieger, E., and Vriend, G. (2014). YASARA View-molecular graphics for all devices-from smartphones to workstations. Bioinformatics 30, 2981-2982. doi: 10.1093/bioinformatics/btu426

Kumar, R. S., Thajuddin, N., and Venkateswari, C. (2010). Antibacterial activity of cyanolichen and symbiotic cyanobacteria against some selected microorganisms. Afr. J. Microbiol. Res. 4, 1408-1411.

Kumar, S., Jyotirmayee, K., and Sarangi, M. (2013). Thin layer chromatography: a tool of biotechnology for isolation of bioactive compounds from medicinal plants. Int. J. Pharm. Sci. Rev. Res. 18, 126-132.

Lahlou, M. (2013). The success of natural products in drug discovery. Pharmacol. Pharm. 4, 17-31. doi: 10.4236/pp.2013.43A003

Lawton, L. A., Edwards, C., and Codd, G. A. (1994). Extraction and high performance liquid chromatographic method for the determination of microcystins in raw and treated waters. Analyst 119, 1525-1530. doi: 10.1039/an9941901525 
Mayer, A. M. S., and Hamann, M. T. (2005). Marine Pharmacology in 2001-2002. Marine compounds with anthelmintic, antibacterial, anticoagulant, antidiabetic, antifungal, anti-inflammatory, antimalarial, antiplatelet, antiprotozoal, antituberculosis and antiviral activities, affecting the cardiovascular, immune and nervous systems and other miscellaneous mechanisms of action. Comp. Biochem. Physiol. 140, 265-286. doi: 10.1016/j.cca.2005.04.004

McKillop, D., Partridge, A. E., Kemp, J. V., Spence, M. P., Kendrew, J., Wood, P. G., et al. (2005). Tumor penetration of gefitinib (Iressa), an epidermal growth factor receptor tyrosine kinase inhibitor. Mol. Cancer Ther. 4, 641-649. doi: 10.1158/1535-7163.MCT-04-0329

Morris, G. M., Goodsell, D. S., Halliday, R. S., Huey, R., Hart, W. E., Belew, R. K., et al. (1998). Automated docking using a Lamarckian genetic algorithm and an empirical binding free energy function. J. Comput. Chem. 19, 1639-1662. doi: 10.1002/(SICI)1096-987X(19981115)19:14<1639::AID-JCC10>3.0.CO;2-B

Namikoshi, M., and Rinehardt, K. L. (1996). Bioactive compounds produced by cyanobacteria. J. Ind. Microbiol. Biotechnol. 17, 373-384. doi: $10.1007 / \mathrm{BF} 01574768$

Nikaido, H. (2003). Molecular basis of bacterial outer membrane permeability revisited. Microbiol. Mol. Biol. Rev. 67, 593-656. doi: 10.1128/MMBR.67.4.593-656.2003

Nikitas, P., and Pappa-Louisi, A. (2009). Retention models for isocratic and gradient elution in reverse phase liquid chromatography. J. Chromatogr. A 1216, 1737-1755. doi: 10.1016/j.chroma.2008.09.051

Nübel, U., Garcia-Pichel, F., and Muyzer, G. (1997). PCR primers to amplify 16S rRNA genes from Cyanobacteria. Appl. Environ. Microbiol. 63, 3327-3332.

Paterson, D. L. (2006). The epidemiological profile of infections with multidrugresistant Pseudomonas aeruginosa and Acinetobacter species. Clin. Infect. Dis. 43, S43-S48. doi: 10.1086/504476

Patterson, G. M. L., Larsen, L. K., and Moore, R. E. (1994). Bioactive natural products from blue-green algae. J. Appl. Phycol. 6, 151-157. doi: $10.1007 / \mathrm{BF} 02186069$

Prasanna, R., Sood, A., Jaiswal, P., Nayak, S., Gupta, V., Chaudhary, V., et al. (2010). Rediscovering cyanobacteria as valuable sources of bioactive compounds. Appl. Biochem. Microbiol. 46, 119-134. doi: 10.1134/S0003683810020018

Quilliam, M. A. (2003). The role of chromatography in the hunt for red tide toxins. J. Chromatogr. A 1000, 527-548. doi: 10.1016/S0021-9673(03)00586-7

Reynolds, R., Potz, N., Colman, M., Williams, A., Livermore, D., and MacGowan, A. (2004). Antimicrobial susceptibility of the pathogens of bacteraemia in the UK and Ireland 2001-2002: the BSAC bacteraemia resistance surveillance programme. J. Antimicrob. Chemother. 53, 1018-1032. doi: 10.1093/jac/dkh232

Rippka, R., Deruelles, J., Waterbury, J. B., Herdman, M., and Stanier, R. Y. (1979). Generic assignments, strain histories and properties of pure cultures of cyanobacteria. J. Gen. Microbiol. 111, 1-61. doi: 10.1099/00221287-111-1-1

Saitou, N., and Nei, M. (1987). The neighbor-joining method: a new method for reconstructing phylogenetic trees. Mol. Biol. Evol. 4, 406-425.

Singh, P., Singh, S. S., Aboal, M., and Mishra, A. K. (2015). Decoding cyanobacterial phylogeny and molecular evolution using an evonumeric approach. Protoplasma 252, 519-535. doi: 10.1007/s00709-014-0699-8

Singh, S., Kate, B. N., and Banerjee, U. C. (2005). Bioactive compounds from cyanobacteria and microalgae: an overview. Crit. Rev. Biotechnol. 25, 73-95. doi: 10.1080/07388550500248498

Sivonen, K., and Börner, T. (2008). "Bioactive compounds produced by cyanobacteria," in The Cyanobacteria; Molecular Biology, Genomics and Evolution, eds A. Herrero and E. Flores (Norflok: Caster Academic Press), 159-197.
Snyder, L. R., and Dolan, J. W. (2006). Initial experiments in high-performance liquid chromatographic method development I. Use of a starting gradient run. J. Chromatogr. A 721, 3-14. doi: 10.1016/0021-9673(95)00770-9

Srivastava, A., Tiwari, R., Srivastava, V., Singh, T. B., and Asthana, R. K. (2015). Fresh water cyanobacteria Geitlerinema sp. CCC728 and Arthrospira sp. CCC729 as an anticancer drug resource. PLoS ONE 10:e0136838. doi: 10.1371/journal.pone.0136838

Tamura, K., Stecher, G., Peterson, D., Filipski, A., and Kumar, S. (2013). MEGA6: molecular evolutionary genetics analysis version 6.0. Mol. Biol. Evol. 30, 2725-2729. doi: 10.1093/molbev/mst197

Trimurtulu, G., Ohtani, I., Patterson, G. M. L., Moore, R. E., Corbett, T. H., Valeriote, F. A., et al. (1994). Total structures of cryptophycins, potent antitumor depsipeptides from the blue-green alga Nostoc sp. strain GSV 224. J. Am. Chem. Soc. 116, 4729-4737. doi: 10.1021/ja00090a020

Trott, O., and Olson, A. J. (2010). AutoDock VINA: improving the speed and accuracy of docking with a new scoring function, efficient optimization and multithreading. J. Comput. Chem. 31, 455-461. doi: 10.1002/jcc.21334

Vicens, Q., and Westhof, E. (2001). Crystal structure of paromomycin docked into the eubacterial ribosomal decoding A site. Structure 9, 647-658. doi: 10.1016/S0969-2126(01)00629-3

Vicens, Q., and Westhof, E. (2002). Crystal structure of a complex between the aminoglycoside tobramycin and an oligonucleotide containing the ribosomal decoding a site. Chem. Biol. 9, 747-755. doi: 10.1016/S1074-5521(02)00153-9

Vicens, Q., and Westhof, E. (2003). Crystal structure of geneticin bound to a bacterial 16S ribosomal RNA A site oligonucleotide. J. Mol. Biol. 326, 1175-1188. doi: 10.1016/S0022-2836(02)01435-3

Vishwakarma, R., and Rai, A. K. (2013). Separation of bioactive metabolites from Aphanothece halophytica through HPLC and characterization of the analytes through ESI-MS and NMR. J. Nat. Prod. 3, 151-157. doi: 10.2174/2210315511303020010

Weisburg, W. G., Barns, S. M., Pelletier, D. A., and Lupski, J. R. (1991). 16S Ribosomal DNA amplification for phylogenetic study. J. Bacteriol. 173, 697-703. doi: 10.1128/jb.173.2.697-703.1991

Willmann, J., Thiele, H., and Leibfritz, D. (2011). Combined reversed phase HPLC, mass spectrometry and NMR spectroscopy for a fast separation and efficient identification of phosphatidylcholines. J. Biomed. Biotechnol. 2001:385786. doi: $10.1155 / 2011 / 385786$

Wilson, D. N. (2014). Ribosome-targeting antibiotics and mechanisms of bacterial resistance. Nat. Rev. Microbiol. 12, 35-48. doi: 10.1038/nrmicro3155

Zhang, Z., Li, Y., Lin, B., Schroeder, M., and Huang, B. (2011). Identification of cavities on protein surface using multiple computational approaches for drug binding site prediction. Bioinformatics 21, 2083-2088. doi: 10.1093/bioinformatics/btr331

Ziervogel, B. K., and Roux, B. (2013). The binding of antibiotics in OmpF porin. Structure 21, 76-87. doi: 10.1016/j.str.2012.10.014

Conflict of Interest Statement: The authors declare that the research was conducted in the absence of any commercial or financial relationships that could be construed as a potential conflict of interest.

Copyright (C) 2016 Niveshika, Verma, Mishra, Singh and Singh. This is an open-access article distributed under the terms of the Creative Commons Attribution License (CC $B Y)$. The use, distribution or reproduction in other forums is permitted, provided the original author(s) or licensor are credited and that the original publication in this journal is cited, in accordance with accepted academic practice. No use, distribution or reproduction is permitted which does not comply with these terms. 